\title{
Urbanization in Iron Age Europe: Trajectories, Patterns, and Social Dynamics
}

\author{
Manuel Fernández-Götz ${ }^{1}$
}

Published online: 17 August 2017

(C) The Author(s) 2017. This article is an open access publication

\begin{abstract}
The development of the first urban centers is one of the most fundamental phenomena in the history of temperate Europe. New research demonstrates that the earliest cities developed north of the Alps between the sixth and fifth centuries BC as a consequence of processes of demographic growth, hierarchization, and centralization that have their roots in the immediately preceding period. However, this was an ephemeral urban phenomenon, which was followed by a period of crisis characterized by the abandonment of major centers and the return to more decentralized settlement patterns. A new trend toward urbanization occurred in the third and second centuries BC with the appearance of supra-local sanctuaries, open agglomerations, and finally the fortified oppida. Late Iron Age settlement patterns and urban trajectories were much more complex than traditionally thought and included manifold interrelations between open and fortified sites. Political and religious aspects played a key role in the development of central places, and in many cases the oppida were established on locations that already had a sacred character as places for rituals and assemblies. The Roman conquest largely brought to an end Iron Age urbanization processes, but with heterogeneous results of both abandonment and disruption and also continuity and integration.
\end{abstract}

Keywords Urbanization · Temperate Europe · Iron Age · Fürstensitze · Open settlements · Oppida

Manuel Fernández-Götz

M.Fernandez-Gotz@ed.ac.uk

1 School of History, Classics and Archaeology, University of Edinburgh, William Robertson Wing, Old Medical School, Teviot Place, Edinburgh EH8 9AG, UK 


\section{Introduction}

The first millennium BC was a time of urbanization across Eurasia (Fernández-Götz and Krausse 2016). Although urban centers had a long trajectory in regions such as Mesopotamia (Liverani 2013; Yoffee 2015), the earliest cities of central-western Europe developed during the Iron Age (c. 800-20 BC). These were not the first cities on European soil-the fourth millennium BC Trypillia megasites in Ukraine can probably claim this title (Chapman and Gaydarska 2016; Müller et al. 2016) but the earliest in the regions north of the Alps. Since the seminal work of Déchelette (1914; see also Lukas 2014) in the late 19th and early 20th century and including more recent writings, most scholars have regarded the large fortified oppida of the second and first centuries BC as the first urban centers of temperate Europe, i.e., non-Mediterranean Europe (Alexander 1972; Collis 1984; Cunliffe and Rowley 1976; Fichtl 2005a; Guichard et al. 2000). However, thanks to new investigation strategies and techniques, our understanding of Iron Age centralization and urbanization processes has changed dramatically over the last few decades (Fernández-Götz et al. 2014; Krausse 2010; Sievers and Schönfelder 2012). Largescale research projects in the form of open-area excavations, geophysical surveys, and the use of such methodologies as LIDAR images, 3D laser scanning, and isotope analysis have expanded our knowledge enormously, providing a much more dynamic and complex picture.

In this paper I consider the new archaeological evidence for early urban centers in first millennium BC temperate Europe, from the Atlantic Coast to the east. In most of the analyzed regions, the chronological framework is provided by the Hallstatt (Early Iron Age, 800-450 BC) and the La Tène (Late Iron Age, 450-20 BC) periods, although this terminology does not apply to areas such as Britain or the Iberian Peninsula. Scandinavia is not considered in the article since early urbanism there is a phenomenon of the late first millennium AD (Sindbæk 2007). Some of the main points that I address are the integration of Iron Age urbanization studies into the wider field of comparative urban scholarship; the recognition of an early phenomenon of urbanization in the sixth and fifth centuries $\mathrm{BC}$; the nonlinear character of Iron Age centralization processes; the importance of open agglomerations as centers of craft production and trade; and a reassessment of the genesis and functions of the oppida that takes into account the role of politics and religion.

Despite the considerable attention that hillforts and oppida have attracted since the 19th century, Iron Age centralization processes have rarely been considered from an anthropological perspective; one exception is Oppida: Earliest Towns North of the Alps (Collis 1984). Most approaches have focused on comparisons with the classical world (particularly with Greek and Roman cities), interpreting the appearance of major settlements in temperate Europe as a "barbarian" attempt to emulate Mediterranean urbanization. The widespread distinction between prehistoric and classical studies and therefore between "civilized" south versus "barbarian" north carries important implications for the way Iron Age urbanization processes have been traditionally examined and understood. This includes the use of "checklist approaches" in which the urban character of a site is determined by its 
supposed similarities with the "standard" model of classical cities, or the maintenance of diffusionist views in which cultural change among "passive" central European societies was dependent on the stimuli coming from "active" southern civilizations (e.g., Kimmig 1983). Moreover, whereas scholars working on the Mediterranean Basin make widespread use of the terms "towns" and "cities" to designate a wide range of first millennium BC settlements, the use of such categories is still much discussed for temperate Europe. This reluctance, however, often has more to do with modern prejudices than with the past reality of ancient societies.

In order to achieve a better understating of Iron Age urbanization, it is useful to adopt a broader approach based on the comparative analysis of complex societies (e.g., Smith 2012) and the multiple pathways to aggregation and urbanization in preindustrial societies (Birch 2013; Marcus and Sabloff 2008; Smith 2003; Storey 2006; Yoffee 2015). This is not to deny comparisons with the Mediterranean cultures but to go beyond colonial dualisms and reductionist perspectives that obscure the rich diversity of urban forms in preindustrial societies. The Iron Age is characterized by a high degree of connectivity - as reflected in the transmission of artifacts, ideas, and people-so that intercultural networks need to be taken into account. But rather than seeing urbanization north of the Alps as dependent on the Mediterranean, it is better to envisage two distinct zones that evolved in parallel and in close contact with one another (Collis 2014). Concepts such as "low-density" urbanism (Fletcher 2009, 2012), neighborhoods as universal features of urban life (Smith 2010), or the role of "empty" spaces in urban sites (Smith 2008) can provide particularly fruitful insights for future research.

Building on the above reflections, I follow a context-dependent definition of "city" that recognizes the high levels of variation that often exist between and within different urban traditions: "a numerically significant aggregation of people permanently living together in a settlement which fulfills central place functions for a wider territory" (Fernández-Götz and Krausse 2013, p. 480). Central place, in turn, is defined as "any kind of place with central functions for a supra-local community" (Gerritsen and Roymans 2006, p. 255).

\section{Early Iron Age Urbanism: The Rise of the Fürstensitze (600-400 BC)}

The most spectacular game changer of the last two decades is the widespread recognition of a first period of centralization and early urbanization in the sixth and fifth centuries BC (Brun and Chaume 2013; Fernández-Götz and Krausse 2013). Although the existence of Early Iron Age central places in the regions immediately north of the Alps was known since at least the 1950s, they were thought to be rather small centers of only a few hectares. These so-called Fürstensitze ("princely seats") were characterized as surrounded by rich aristocratic burials under tumuli and by the presence of Mediterranean imports. Recent research has increased the corpus of sites and demonstrated that some of them were considerably larger and more complex than traditionally expected (Krausse 2008a, 2010; Krausse et al. 2016). 
Among the most important sites are Heuneburg, Hohenasperg, Ipf, Glauberg, Mont Lassois, Bourges, Ehrenbürg, Vladař, and Závist (Fig. 1).

\section{Uncovering Low-Density Urbanism}

The Heuneburg agglomeration on the Upper Danube is the most intensively researched of these central places. Systematic open-area excavations have revealed complex and well-preserved stratigraphy on the hilltop plateau, a Mediterraneaninspired mud-brick wall, Greek pottery, and sumptuous elite burials in the surrounding area, and the site has figured prominently in works on Iron Age Europe (Fernández-Götz 2014b; Krausse et al. 2016). For a long time it was thought that the settlement was restricted to 3 ha on the hilltop plateau and to a small exterior settlement of a few hectares; together with the manifold Mediterranean influences, this served to establish comparisons with the acropoleis and suburbia of Greek poleis.

Since the 1990s, large-scale excavations and surveys in the area surrounding the hilltop plateau have revealed the existence of a heavily fortified lower town and an exterior settlement of approximately 100 ha comprising dense groups of farmsteads (Fernández-Götz and Krausse 2013; Krausse et al. 2016; Kurz 2010). These discoveries have profound implications for our understanding of the Heuneburg agglomeration. With an estimated population of 5,000 inhabitants in the first half of the sixth century BC, Heuneburg was larger in both area and dwellers than most contemporaneous Mediterranean settlements, although with a rather low overall

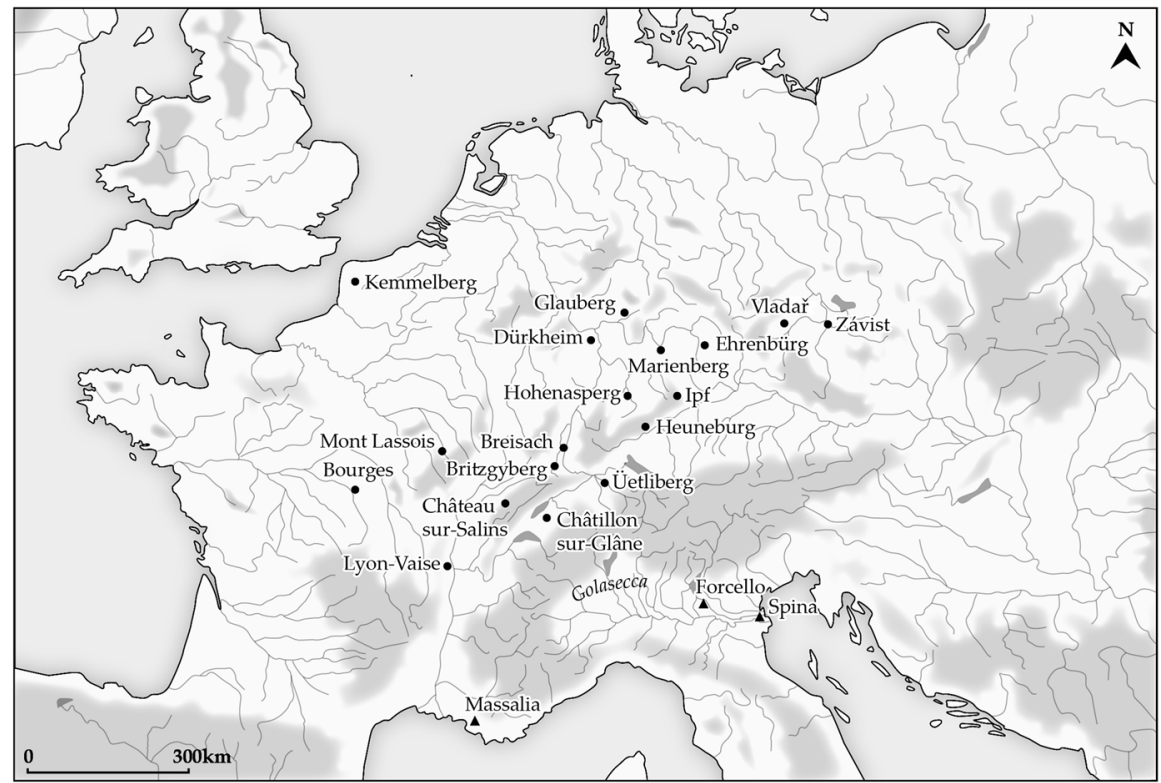

Fig. 1 Distribution of main central places north of the Alps and selected sites in Mediterranean Europe, sixth-fifth centuries BC (after Fernández-Götz and Ralston 2017) 
population density of 50 inhabitants per hectare. Based on evidence of specialized production, marked social inequalities, monumental architecture, a well-planned settlement layout, and large population size, Heuneburg was an early urban center both from a demographic and a functional point of view (e.g., Smith 2014, 2016). The hilltop plateau was densely settled with rows of houses along a network of streets, whereas the large exterior settlement was subdivided by an extensive system of banks and ditches that demarcated different neighborhoods. The latter could have been inhabited by different kinship groups that joined together during the process of synoecism, which underpinned the creation of the agglomeration. The exterior settlement appears to reveal the presence of farmstead-like compounds-some with evidences of artisanal production-within a larger agglomeration. Rather than being the result of gradual population growth, the Heuneburg agglomeration seems to have been created within a short period of time, probably as the result of a political decision that would have brought together different population groups that previously were dispersed in the countryside. However, this large settlement complex lasted for only two-three generations and was largely destroyed by a catastrophic fire around 540-530 BC. After this traumatic event, most of the exterior settlement was abandoned and the exotic mud-brick wall on the plateau was replaced by a wall of earth and timber, following traditional patterns (Krausse et al. 2016).

Not only at Heuneburg has recent fieldwork profoundly changed traditional assumptions about the characteristics of the "Fürstensitze," but also at Bourges in central France are the results equally outstanding. Until a few years ago the settlement was known mainly for the first century BC oppidum of Avaricum that is mentioned in Caesar's Gallic Wars (1970) as the capital of the powerful tribe of the Bituriges. The city of Bourges has been continuously settled up to the present day, so that any reconstruction of the internal structure of the Iron Age settlement is patchy and mainly restricted to peripheral zones. In spite of these limitations, research in the last decade has produced important information on an earlier occupation in the sixth and fifth centuries BC (Augier et al. 2007, 2012; Milcent 2007 , 2014). The agglomeration of Bourges covered several hundred hectares in the fifth century BC, although the density of settlement in some areas was relatively low (Fig. 2). As is the case with several other "Fürstensitze." Bourges comprises an acropolis, suburbs characterized by artisanal activities, and rich elite burials in the surrounding area. The most remarkable aspect of the settlement complex is its enormous scale, which clearly surpasses all other early centers of power in temperate Europe.

Both Heuneburg and Bourges fit well within the model of low-density urbanism as defined by Fletcher (2009, 2012). In contrast to densely occupied settlements that would fit within Childe's (1950) classic model of urbanism, throughout history many urban sites around the world have been characterized by their large areas and manifold functions and also by low-density occupation of often fewer than 50 people per hectare. Although cases such as Angkor, Cahokia, Great Zimbabwe, and Co Loa are among the most famous examples, a large number of late prehistoric European sites also can be added to the list, including the fourth millennium BC Trypillia megasites from Ukraine (Chapman and Gaydarska 2016; Müller et al. 2016), the Early Iron Age 


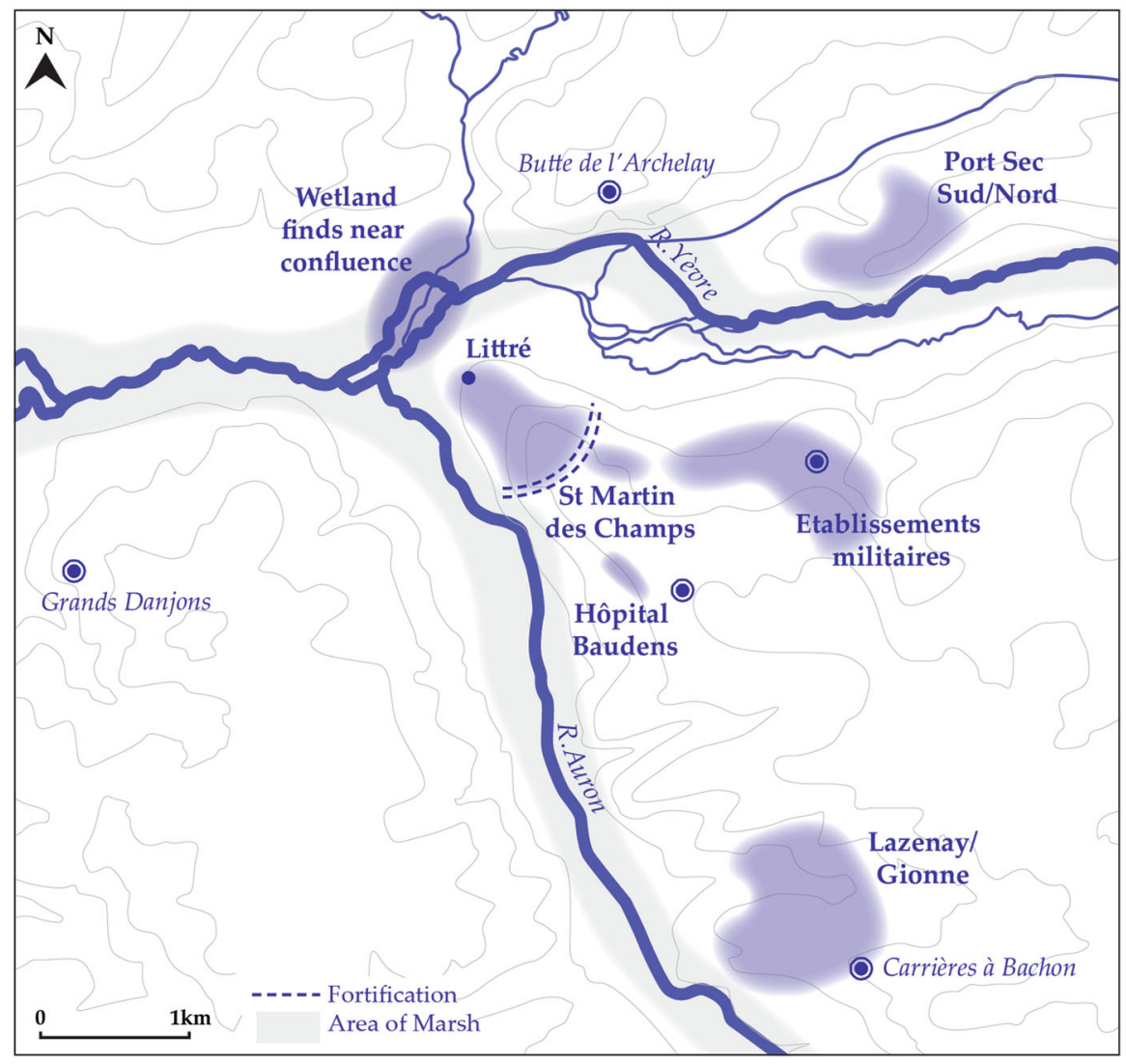

Fig. 2 Bourges: Plan of the agglomeration and its surroundings in the fifth century BC. Shaded areas are main zones of concentration of Early Iron Age activity (after Fernández-Götz and Ralston 2017)

agglomerations discussed above, and the Late Iron Age oppida (see below and Moore 2017). However, we need to be aware of the complexity of existing situations: at Heuneburg, for example, there is the synchronous occurrence of a very high-density occupation in the area of the hilltop plateau and a low-density occupation in the outer settlement. At the same time, neither the Trypillia megasites nor most of the temperate European Iron Age agglomerations follow Fletcher's model of an urban trajectory in which cities that initially had high densities later became not only increasingly large but also increasingly lower density.

\section{Heterogeneity and Similarity in Early Centralization}

Other Early Iron Age central places, however, present different characteristics. At Mont Lassois, for example, there is no evidence of a large external settlement; instead several monumental apsidal buildings and a well-planned settlement with enclosures and main road axis have been identified and partly excavated on the plateau (Chaume and Mordant 2011; Chaume et al. 2013) (Fig. 3). At the settlement 

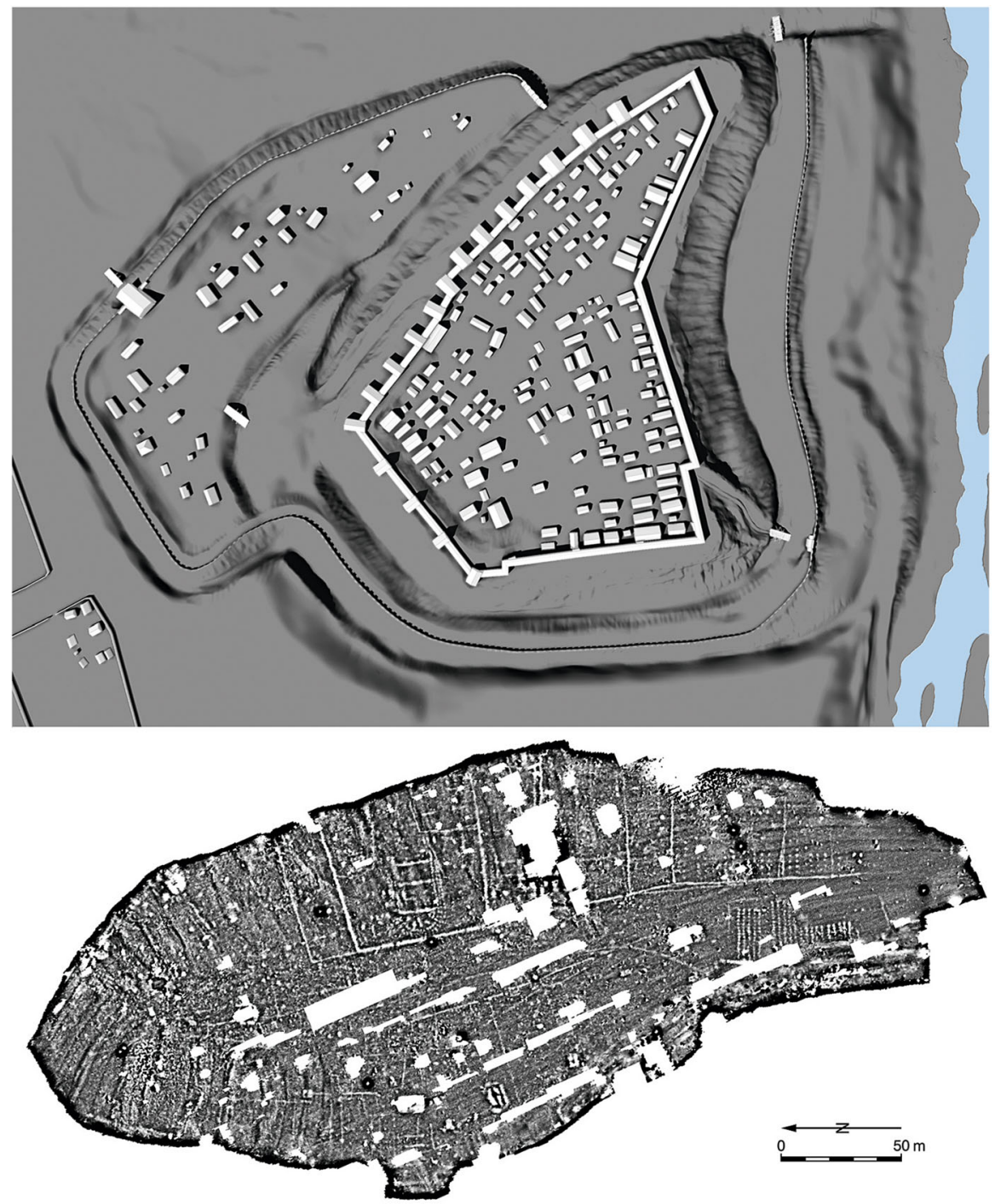

Fig. 3 Two examples of regular building arrangements that are indicative of genuine urban planning in the sixth century BC. Top Heuneburg hilltop plateau and lower town, buildings during the mud-brick wall period. Bottom Mont Lassois, geomagnetic plan of the plateau (after Krausse et al. 2016 and P.C.R. Vix)

of Ehrenbürg bei Forchheim, covering 36 ha, more than 20,000 storage pits dug into the bedrock were identified during geophysical surveys (Abels 2005, 2010). The Glauberg, for its part, stands out rich sumptuous burials, the heroon, and the monumental ditch-and-bank system with a 350-m-long processional way at the foot of the fortified plateau (Baitinger 2010; Baitinger and Pinsker 2002). Everything suggests that this was a religious point of reference that provided a sense of common identity for various tribes or regional groupings (Herrmann 2005). The association 
with the worship of heroized-maybe even divinized-ancestors seems clear; the same applies to the sanctuary enclosure of Vix 'Les Herbues' at the foot of Mont Lassois (Chaume and Reinhard 2007). Evidence for large communal sanctuaries is still rare for the Early Iron Age; one of the few known exceptions is the acropolis of Závist, where different temple buildings have been excavated and interpreted as the central sanctuary of a tribal polity (Drda and Rybová 2008).

Monumental fortifications; profane, sacral, and funerary architecture; workshop areas; and Mediterranean imports highlight the manifold functions of the "Fürstensitze." Imposing fortifications with banks, ditches, walls, and gates, such as those found at Heuneburg, Ipf, and Mont Lassois, had a clear defensive significance, but they also embodied the power of the communities. The concentration of sumptuous burials in the environs of the central places (e.g., Hohmichele, Gießübel-Talhau, Hochdorf, Grafenbühl, Sainte-Colombe, Vix) is, among other things, an indication of the political and administrative functions of these settlements (Krausse 2006b; Verger 2015). Rich child burials such as those of Heuneburg-Bettelbühl or Bourges indicate ascribed and inherited rank and status. Craft and technical functions, as well as economic and mercantile ones, are reflected in the presence of workshops for specialized craftsmen-even entire areas on the margins of Bourges are dedicated to crafts-as well as by imported goods. Significant economic activity and Mediterranean imports were not only restricted to the main fortified sites but also were present at open settlements such as Bragny-surSaône and Hochdorf-Reps (Biel 2015; Collet and Flouest 1997; Modarressi-Tehrani 2009). Proto-industrial iron production is attested in the Neuenbürg mining district in the northern Black Forest (Gassmann and Wieland 2015).

Taking a broader look, the development of Early Iron Age central places can be regarded as the crystallization of the first urbanization processes north of the Alps, preceding the Late Iron Age oppida by more than four centuries. With regard to the social typologies that have been defined by such authors as Johnson and Earle (2000), these were hierarchically organized societies that can best be regarded as transitional between complex chiefdoms and early states (Fernández-Götz and Krausse 2013; Ralston 2010). Despite the fact that not all "Fürstensitze" can be regarded as urban, they all were complex central places that carried out central place functions for the populations of their hinterlands. Although heterogeneous in their layout, occupied area, functions, and lifespan (Fernández-Götz and Ralston 2017), the "Fürstensitze" very likely represented focal settings for tribal polities that might have maintained political and economic relations of the types proposed in the peerpolity-interaction model (Renfrew and Cherry 1986). The nearly regular spatial distribution of these major centers (see Fig. 1) has been compared with the territories of Maya states (Renfrew 2016); they likely were at the top of settlement hierarchies. Going a step farther, we can try to establish networks of settlement centrality and dependence within the territory of some "Fürstensitze," for example, in the region around the Heuneburg agglomeration where a number of secondary hillforts are currently under investigation as part of a large research project (Hansen et al. 2015; Krausse et al. 2016). Stable isotope analysis further enriches this picture, since during the mud-brick wall period of Heuneburg, with its highly concentrated 
population, a significant proportion of the animals were imported over a distance of 50-60 km (Schatz and Stephan 2008).

\section{Mediterranean Influence or Indigenous Development?}

The traditionally prevailing model sees the foundation of the Greek colony of Massalia (Marseille) in southern France around $600 \mathrm{BC}$ as the prime mover for the development of the "Fürstensitze" (e.g., Kimmig 1983). This interpretation can no longer be sustained. The agglomeration at Heuneburg started in the late seventh century BC, at least one generation before the foundation of Massalia, and Greek imports mostly postdate the destruction of the mud-brick wall (Krausse et al. 2016). Moreover, funerary evidence from the eighth and seventh centuries BC confirms that the rise of social hierarchies and the development of local power elites had already started several decades before the foundation of the major settlements (Van der Vaart-Verschoof and Schumann 2017). Contacts with the Mediterranean certainly played a role in cultural change, but they can be regarded mainly as the consequence of and not the cause for the development of the "Fürstensitze." These temperate European societies share many structural similarities with the Etruscan communities in central Italy (Leighton 2013; Riva 2010), and overall the Italian connection seems much more important than the exchange with Massalia, at least until the late sixth century BC. But rather than explaining temperate European centralization processes as a consequence of the diffusion of Mediterranean stimuli, we should envisage analogous and largely parallel social trends in regions such as Greece, Etruria, and the territories immediately north of the Alps (Brun and Chaume 2013; Fernández-Götz and Krausse 2016). Their development is intimately linked with endogenous processes of demographic growth, social hierarchization, and production intensification.

Analysis of vegetational history indicates that in the sixth century BC for the first time there was dense settlement in many of the upland regions north of the Alps, areas with relatively poor climatic and agricultural conditions. This process of settling new land must have been immediately preceded by a period of population increase (Krausse and Nakoinz 2000). We can assume that apart from technical innovations such as iron production and politico-organizational improvements, a period of climatically favorable conditions in the late seventh and sixth centuries BC also led to a growth in population and the settlement of new areas (FernándezGötz 2014a; Krausse 2006a). These factors-population increase and the opening up of new areas to agriculture and other economic resources-formed the real basis of the wealth of the social elite that is so impressively visible in the form of sumptuous graves. It is probable that the social upper class played a decisive role in the process of centralization (Buchsenschutz and Ralston 2012).

The "Fürstensitze" represent a significant stage in the cultural and political development of later prehistoric central Europe. The appearance of these major centers, however, remains the exception and not the rule in Early Iron Age landscapes beyond the Mediterranean. The northernmost example is Kemmelberg in west Flanders (Bourgeois et al. 2006), and no comparable settlements are known from other regions in central-northern Europe. Sites that assumed central place 
functions certainly existed, but their scale was markedly different from the "Fürstensitze." Among the most interesting examples are the strongholds of northern Poland, of which Biskupin constitutes the prime example. This small settlement of about 2 ha is particularly striking because of its regular layout with rows of streets and identical houses, while at the same time it lacks any evidence of social stratification (Piotrowski 1995). Evidence of social differentiation is much more clearly observed in the southeastern Alpine region and in Hungary, where centers of power such as Stična and Sopron-Burgstall present a combination of a fortified settlement on a hill and concentrations of tumuli in the immediate surrounding area (Gabrovec 1974; Jerem 2012). Recent work at Stična and Kaptol has demonstrated the existence of a previously unexpected dense internal settlement organized on an orthogonal pattern (https://entrans-arch.com/index.php/outputs).

In central Spain, we can identify a trend toward nucleated settlement that led to the development of the villages of the Soto de Medinilla culture in the middle Duero Valley and hillforts such as those of the Sorian uplands (Álvarez-Sanchís and RuizZapatero 2014; Ruiz-Zapatero 2011). Their small size, lack of specialized production, and rather homogeneous material culture indicate a seminal stage of centralization that cannot yet be classified as urban. The same applies to the hillforts of the British Isles, where some regional clusters with dense occupation can be identified (Harding 2012). A well-researched example is the Danebury region in central-southern Britain, where the hillforts of Danebury, Bury Hill, Figsbury, and Quarley provide some evidence of being built in this early stage of the Iron Age; they are spaced fairly regularly between 8 to $11 \mathrm{~km}$ apart from each other (Cunliffe 2005).

\section{Crisis and Recovery: From Decentralization to Open Agglomerations (400-150 BC)}

\section{Urbanization as a NonLinear Phenomenon}

The rise of the "Fürstensitze" was the first wave of early urbanization north of the Alps. However, and in contrast to the centralization processes observed in some areas of the Mediterranean Basin (Garcia 2013; Osborne and Cunliffe 2005), their development in temperate Europe was a short-lived phenomenon, followed by a period of decentralization in which the major centers of the sixth and fifth centuries BC were abandoned (Krausse 2008b). During the fourth and early third centuries $\mathrm{BC}$ we see a return to more decentralized settlement patterns (Buchsenschutz et al. 2012), without major agglomerations and with a reduction of social inequalities. The archaeological record of the Iron Age shows a clear discontinuity, and there was no continual evolutionary development on a European scale from simple to larger and more complex forms of settlements. Instead we can identify multilayered, changing, and dynamic cycles of centralization and decentralization that document the nonlinear nature of history (Fernández-Götz 2014a; Salač 2012, 2014). This situation is by no means exceptional or restricted to Europe; many early cities around the world were "fragile" (Yoffee 2015), although traditional narratives have 
tended to emphasize examples of "success" and settlement continuity rather than disruptions. Even the paradigm region for the study of early cities, the Near East, underwent various cycles of urbanization separated by periods of crisis and even collapse (Liverani 2013).

To understand these processes, it is necessary to combine a macro- and microscale approach. On an individual site level, each settlement has its own biography with different phases of growth, decay, and abandonment, but from a macroregional perspective certain patterns and similarities can be observed. Heuneburg was abandoned around the middle of the fifth century BC, more or less at the same time as Mont Lassois. In both cases there are clear indications of violent destruction, which points to conflict scenarios involving social turmoil and/ or episodes of intertribal warfare. For example, at Mont Lassois the heads of the two human statues located at the entrance to the enclosure of Vix 'Les Herbues' were broken off as a result of the violent destruction of the sanctuary. A catastrophic fire that almost completely destroyed the fortification and the buildings within the acropolis sealed the fate of Heuneburg; the fact that the destruction level was relatively full of finds militates against the idea that the abandonment of the site was planned. In contrast, many other central places, for example Bourges, Glauberg, Bad Dürkheim, Hohenasperg, and Ipf, maintained or even increased their importance during the second half of the same century. But they too were abandoned no later than the end of the fifth or the beginning of the fourth century BC.

During the second half of the fifth and the first half of the fourth century BC, a new generation of large hilltop centers such as Wallendorf, Otzenhausen, Étalle, and possibly Titelberg emerged in the Middle Rhine-Moselle region, at the periphery of the previous "Fürstensitze" area. However, most of them seem to have been temporary assembly sites or places for refuge rather than urban centers. Their permanent population, if any, would generally have been small, and there are no signs of intensive craft production or long-distance trade (Fernández-Götz 2014a). In the course of the fourth century BC these new central places were also abandoned, and only small hillforts of a few hectares continued to exist or were newly founded between this area and the northern German plains; examples include Altburg bei Bundenbach in the Hunsrück region (Nortmann 1990) and Schnippenburg in Lower Saxony (Möllers 2009; Schulze-Forster 2007).

Overall, the chronology of central places and sumptuous burials displays a certain décalage in the development of the processes of centralization and urbanization in central Europe, which first began in the late seventh and sixth centuries $\mathrm{BC}$ in the regions immediately north of the Alps, from Burgundy to Württemberg. Already in the fifth century BC the phenomenon had reached the area between Bohemia and Champagne (Fig. 4). But in contrast to what usually happened in Mediterranean regions, in central Europe the stages of centralization were short lived and followed by periods of regression in which more decentralized and apparently less unequal structures gained ascendency. Thus the level of complexity of urban settlements such as at Heuneburg, Mont Lassois, and Bourges was not reached again until the oppida of the second and first centuries BC. 


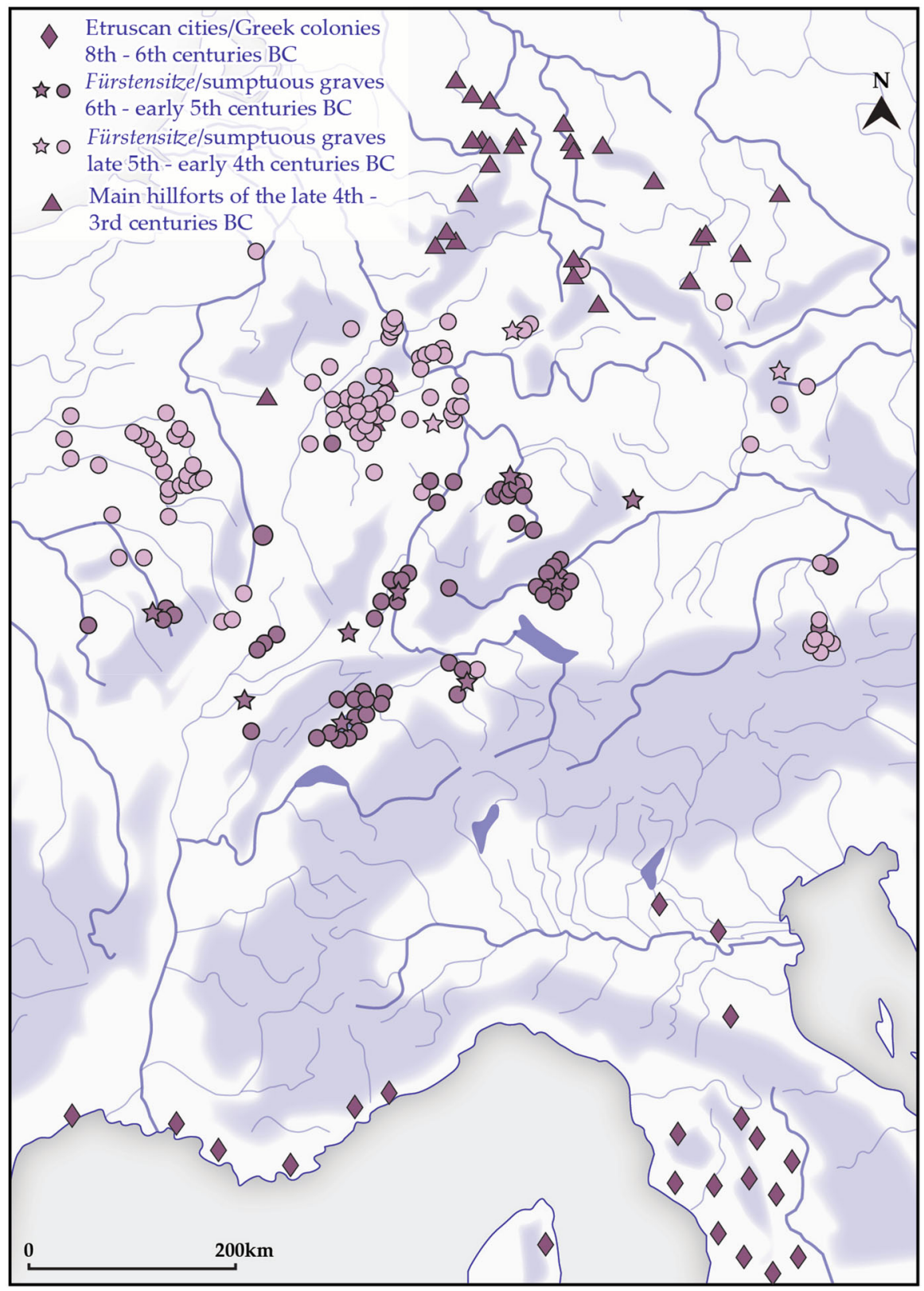

Fig. 4 Centralization processes between central Italy and northern Germany, eighth-third centuries BC (after Krausse 2008b, modified by author) 


\section{Push Factors: Internal Tensions and Climatic Changes}

The reasons for these dynamic transformations and disruptions in the landscapes of power must have been manifold, so that monocausal explanations are insufficient. In any case, it can be assumed that the changes did not always take place peacefully (Fernández-Götz in press; Pauli 1985). Some major centers of power were almost completely burned down; Heuneburg is one example. Equally striking is the conscious mutilation of ancestral images - probably depicting heroized ancestors or founding heroes-which includes the two statues from Les Herbues at Mont Lassois and three of the four anthropomorphic sculptures from Glauberg. Some authors have interpreted this destruction as a reaction against the elites, which can be summarized by the expression "societies against the princes" used by Demoule (1999). Significantly, similar phenomena appeared around the same time in other parts of Iron Age Europe, including the southeastern Iberian Peninsula (Chapa 1993).

The end of the "Fürstensitze" coincides with the start of the period of the socalled Celtic migrations recorded in classical sources, during the course of which high populations migrated from temperate Europe to the south, particularly toward Italy and the Balkans (Tomaschitz 2002). A significant population decrease occurred in many temperate European regions, from Champagne to the Middle Rhine and Württemberg. Whereas some major settlements were violently destroyed, others underwent a planned abandonment. A good example of the latter scenario can be found at Bourges, where the apparently planned abandonment of the external craft sector of Port Sec at the end of the fifth century BC has been linked by some scholars to the description by Livy of the mass emigration of part of the Bituriges and other Gallic tribes (Milcent 2007); according to Livy (1924, book V, section 34), this was the result of a political decision taken to reduce problems that derive from overpopulation.

In a broader perspective, the separation of part of the group is a solution frequently used to reduce the tensions that threaten the equilibrium of communities (Brun 1995); historical examples include the beginnings of Greek colonization across the Mediterranean and the Black Sea or the Viking expansion in the North Atlantic. Migrations can indeed act as regulatory mechanisms for power relations, in the sense that the emigration of part of the population can be a means of releasing social tensions and reducing social inequality in situations of increased scalar stress (Demoule 2006; Kristiansen 1998). In Iron Age temperate European societies, population fission could have served as a reaction to the increasing inequalities of the sixth and fifth centuries $\mathrm{BC}$ and as a way to manage growing tensions derived from intra- and intergroup competition for power and resources. In a further step, during the course of history numerous societies have developed strategies aimed to avoid or counteract the development of state-like structures (Scott 2009; Testart 2005); this is well reflected in the expression, "societies against the state" popularized by Clastres (1989) and frequently includes reducing population size.

Among the causes that have been discussed in recent years as possible push factors for the crisis of the fifth-fourth centuries BC are climate changes. Analysis of cores from the Greenland icecap indicates that as early as the first half of the fifth century $\mathrm{BC}$ temperatures dropped in the entire northern hemisphere, followed by a 
rapid climatic decline around $400 \mathrm{BC}$; this was linked to a reduction of solar activity and appears to have occurred relatively abruptly (Maise 1998; Sirocko 2009). This phenomenon correlates with the beginning of the historically documented migrations of Gallic populations to Italy around 400 BC and their sack of Rome in 387 BC. Although the cooler climate did not make the settlement areas in southern Germany or central-eastern France uninhabitable, it could have resulted in bad harvests, particularly in the relatively unfavorable regions of the highlands that had been occupied for only a few generations, and so led to social tensions and migration. The possibility of episodes of "cascading-effect" needs to be taken into account.

From a macroscale perspective, the main climatic phases of the first millennium $\mathrm{BC}$ do indeed correspond with the most important stages of centralization and decentralization north of the Alps (Brun and Ruby 2008; Fernández-Götz 2014a). Thus the processes of centralization that gave rise to the development of the Early Iron Age "Fürstensitze" and the Late Iron Age oppida took place in predominantly warmer periods, while the migrations of the fourth century BC occurred during a colder phase (Fig. 5). However, if we look at the situation in detail, then it is clear that there were numerous nuances and exceptions. For example, environmental indicators do not explain why some "Fürstensitze" such as Heuneburg or Mont Lassois were abandoned around the middle of the fifth century BC, while others such as the Breisacher Münsterberg, Hohenasperg, and Glauberg continued to function and flourish during the second half of the same century. Similarly, while the abandonment of Bourges and the marked population drop in the Champagne area at the beginning of the fourth century BC appear to coincide fairly closely with climatic changes, which probably prompted a considerable part of the population to emigrate, the centers of the Middle Rhine-Moselle region continued to exist for several decades and were abandoned only in the course of that century.

In sum, worsening climate does not represent the sole explanation for the transformations that occurred during the late fifth and the fourth centuries BC, even though either directly or indirectly it was certainly a significant factor in cultural change. The processes of demographic growth and urbanization during the seventh to fifth centuries BC were accompanied by an increase in social density-i.e., the frequency of communications and interactions between individual persons and groups-competition, and control. This would have led to increasing pressure on resources, growing inequalities between and within groups, and the integration of persons and communities into wider socio-organizational networks. In such a context, climate changes could have exacerbated already growing social tensions and led to a rise of intergroup competition, warfare, and maybe also internal rebellions. At a more general level, the threshold limits of settlement growth also need to be considered (e.g., Fletcher 2007), particularly for larger centers such as Heuneburg and Bourges. The counterreaction was deurbanization, fission of groups, and a return to more fluid power structures. 


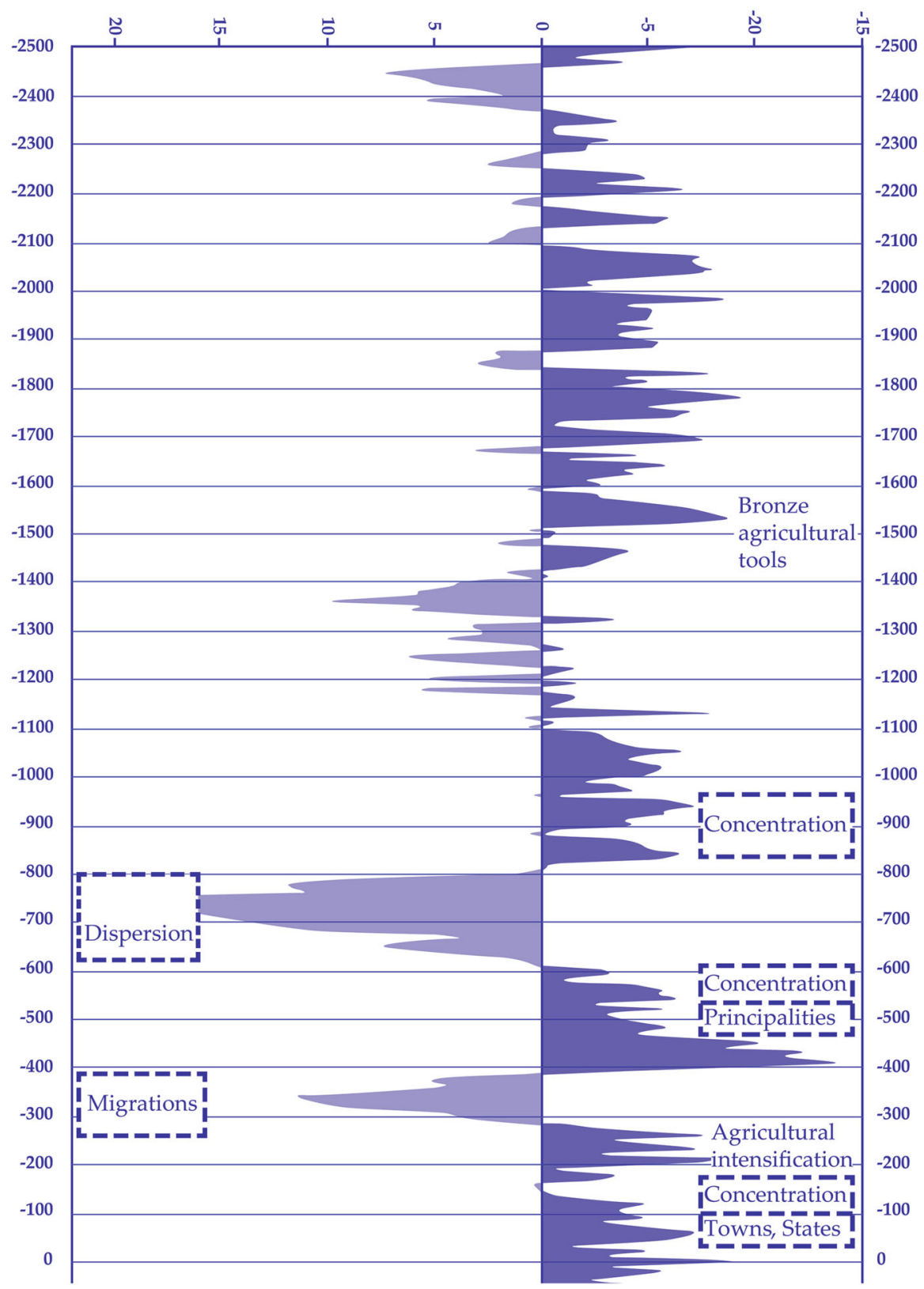

Fig. 5 Evolution of solar activity between c. $2500 \mathrm{BC}$ and the beginning of the first millennium AD, with cold periods on the left and warmer periods on the right (after Brun and Ruby 2008, modified by author) 


\section{A Mosaic of Urban Trajectories: From Britain to Iberia}

The above-described sequence of centralization-decentralization, however, does not apply to all regions of non-Mediterranean Europe. Britain and central-northern Iberia, for example, show a different, more gradual development from smaller to larger settlements during the course of the Iron Age (Almagro-Gorbea 1995; Álvarez-Sanchís et al. 2011; Cunliffe 2005). Although this statement needs to be nuanced on the grounds of the lower chronological resolution of the available data for these regions - which could potentially imply that a short settlement hiatus often remains unnoticed-it seems clear that there is no single path to urbanization. In Britain, several early hillforts from the previous phase were abandoned, whereas others continued to exist and were refortified and/or enlarged (Cunliffe 2005; Harding 2012). The best-known example is Danebury in Hampshire; large parts of the defensive structures and nearly $60 \%$ of the 5-ha inner area have been systematically excavated, providing evidence for a dense occupation with round houses and grain storage pits (Cunliffe 1984, 1995). Based on a new Bayesian dating project (Hamilton et al. 2015), the main occupation spans ca. 425-125 cal $\mathrm{BC}$, though there was some earlier activity (Haselgrove et al. in press). During this long period of occupation, Danebury was remodeled several times, becoming more complex and growing into a "developed hillfort" (Sharples 2014).

In central Iberia, the fourth century $\mathrm{BC}$ witnessed the development of the large settlements that would constitute the later oppida of the Vettones and Vaccei areas, for example, Ulaca, Las Cogotas, and Pintia (Ruiz-Zapatero 2011; Ruiz-Zapatero and Álvarez-Sanchís 1995). These sites experienced gradual growth until the Romans encountered them at the end of the Iron Age. Although the information that we have for their initial settlement phases is rather scarce, some of these centers could have already surpassed a population of 1,000 inhabitants in the fourth-third centuries BC.

\section{Beyond Walls-The Rise of Large Open Settlements}

After the period of decentralization, in the regions north of the Alps a new trend toward centralization began during the third century BC. The climatic recovery and the now-widespread use of iron for agricultural tools and implements favored demographic growth and an increase in production and exchange. As an expression of this population growth, between the third and second centuries BC a number of large settlements developed in the form of open agglomerations (Augstein 2006; Collis 1995; Collis et al. 2000; Fichtl 2013; Salač 2009, 2012). These centers, notably Levroux, Aulnat, Acy-Romance, Basel Gasfabrik, Bad Nauheim, BerchingPollanten, Lovosice, Němčice, Roseldorf, and Sajópetri, are distributed in an area stretching from France to Hungary and are located predominantly on economically favorable positions on lowlands (Fig. 6). Their size could be considerable, with some centers reaching several dozen or even more than 100 ha. Although some sites present some kind of symbolic demarcation, they do not exhibit any formal fortification. The importance of these open settlements has only recently been recognized due to the traditional focus of research on the fortified oppida (Salač 


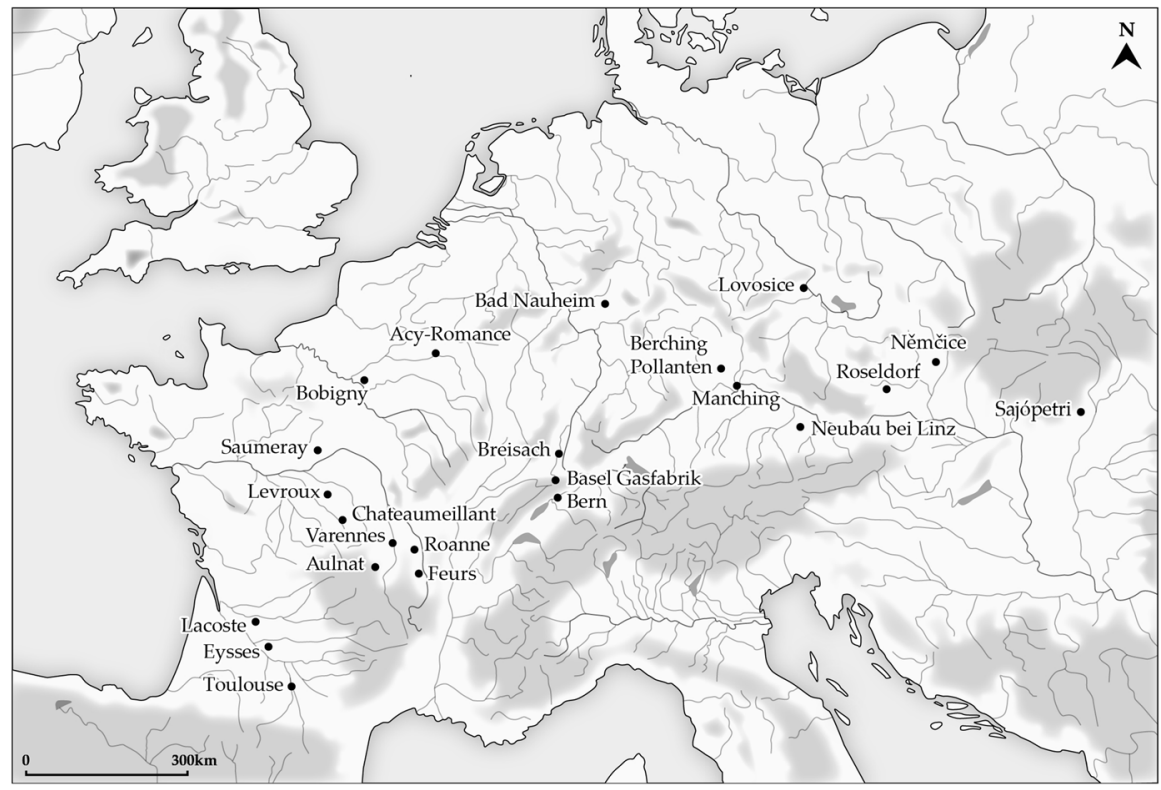

Fig. 6 Distribution of major open settlements with indication of some of the main sites, third-first centuries BC (author)

2009, 2014). Thanks to new research, the corpus of Late Iron Age open agglomerations is constantly expanding, and we should expect new sites to be discovered in coming years, particularly through geophysical prospection, aerial images, and large-scale rescue archaeology projects.

Most open agglomerations developed before the fortified oppida, preceding them by several generations. Some started in the third century BC, although a few, such as Roseldorf, may have been slightly earlier, but overall their main peak took place during the first three-quarters of the second century BC. This early chronology has important consequences for our understanding of Late Iron Age centralization processes, since by the time populations started to concentrate again in major settlements, they did so in open, unfortified sites; this means that defense was not an important factor for population aggregation, at least initially (see below). Moreover, it demonstrates that these processes were of a primarily endogenous nature and not merely a reaction to Rome's military expansion, as was often proposed by scholars in the past.

Many large unfortified settlements were important production and distribution centers that performed economic functions at least equivalent to those of the most prominent oppida. The evidence includes elements such as coin minting, imports originating in distant regions, large-scale metallurgy production, and manufacture of glass objects (Augstein 2006; Salač 2009, 2012). However, there is considerable heterogeneity, and while some sites such as Levroux, Feurs, and Roanne show a clear focus on craft production, others like Acy-Romance present a predominantly agricultural character. 
An aspect that is becoming increasingly evident is the role of cult activities in open agglomerations. Among the most prominent examples are Acy-Romance in the Ardennes-with several temple buildings, evidence for sacrifices, and a central public space used for collective meetings and rites (Lambot 2006) - and Roseldorf in Austria. The latter site is particularly striking due to the discovery of a coin mint and three contemporaneous cult districts with at least two large temples, five smaller ones, and a large sacrificial pit (Fig. 7). The spectrum and the percentage of the offerings indicate differences in ritual and worship between the cult districts at Roseldorf; they may have been dedicated to different gods (Holzer 2014).

Together with the appearance of spaces for ritual activities within large open settlements, the third century BC also witnessed the development of some important supra-local sanctuaries located outside agglomerations, such as Gournay-surAronde, Ribemont-sur-Ancre, and Mirebeau (Arcelin and Brunaux 2003). This is a further indication of processes of coalescence that took place at that time; some authors have even suggested that there might have been a close link between the appearance of these cult centers and the emergence of politicized ethnic identities such as the pre-Roman pagi and civitates mentioned in classical sources (Fichtl 2007, 2012b).

\section{The Age of the Oppida (150 BC-Roman Conquest)}

The final step in the process of Iron Age urbanization was the development of the large fortified centers known as oppida (Collis 1984, 2000; Fernández-Götz 2014c; Fichtl 2005a, 2012a, c; Pierrevelcin 2012; Rieckhoff and Fichtl 2011; Wells 1984). These settlements are more widely distributed than the Early Iron Age "Fürstensitze" (Fig. 8). There are more than 150 oppida from the second and first centuries BC in temperate Europe (Fichtl 2005a), from Atlantic France in the west to Hungary in the east and Britain in the north. The recently published site of Stanwick is the northernmost example (Haselgrove 2016); Manching (Sievers 2007; Wendling 2013), Bibracte/Mont Beuvray (Dhennequin et al. 2008; Guichard and Paris 2013), Titelberg (Metzler 1995; Metzler et al. 2016), and Corent (Poux 2012; Poux and Demierre 2016) are the most intensively investigated sites.

One of the main research challenges in studying the oppida is the enormous size of these sites-in most cases they cover several dozens and sometimes several hundred or more than 1000 ha-which makes it nearly impossible to excavate a significant percentage of their inner area. With new methodologies such as LIDAR images and geophysical surveys, this limitation can now be at least partly overcome. Because of the restricted nature of most excavations, it is difficult to establish demographic estimates, although a population of 5,000-10,000 inhabitants has been proposed for places such as Manching and Bibracte.

The vast majority of oppida developed between the last decades of the second and the early first centuries BC, but some isolated ones such as Závist started one or two generations earlier, already in the first half of the second century BC (Colin 1998; Fichtl 2005a). It is worth noting that some oppida reoccupied places that already had been fortified during earlier stages of the Iron Age, including Bourges/ 

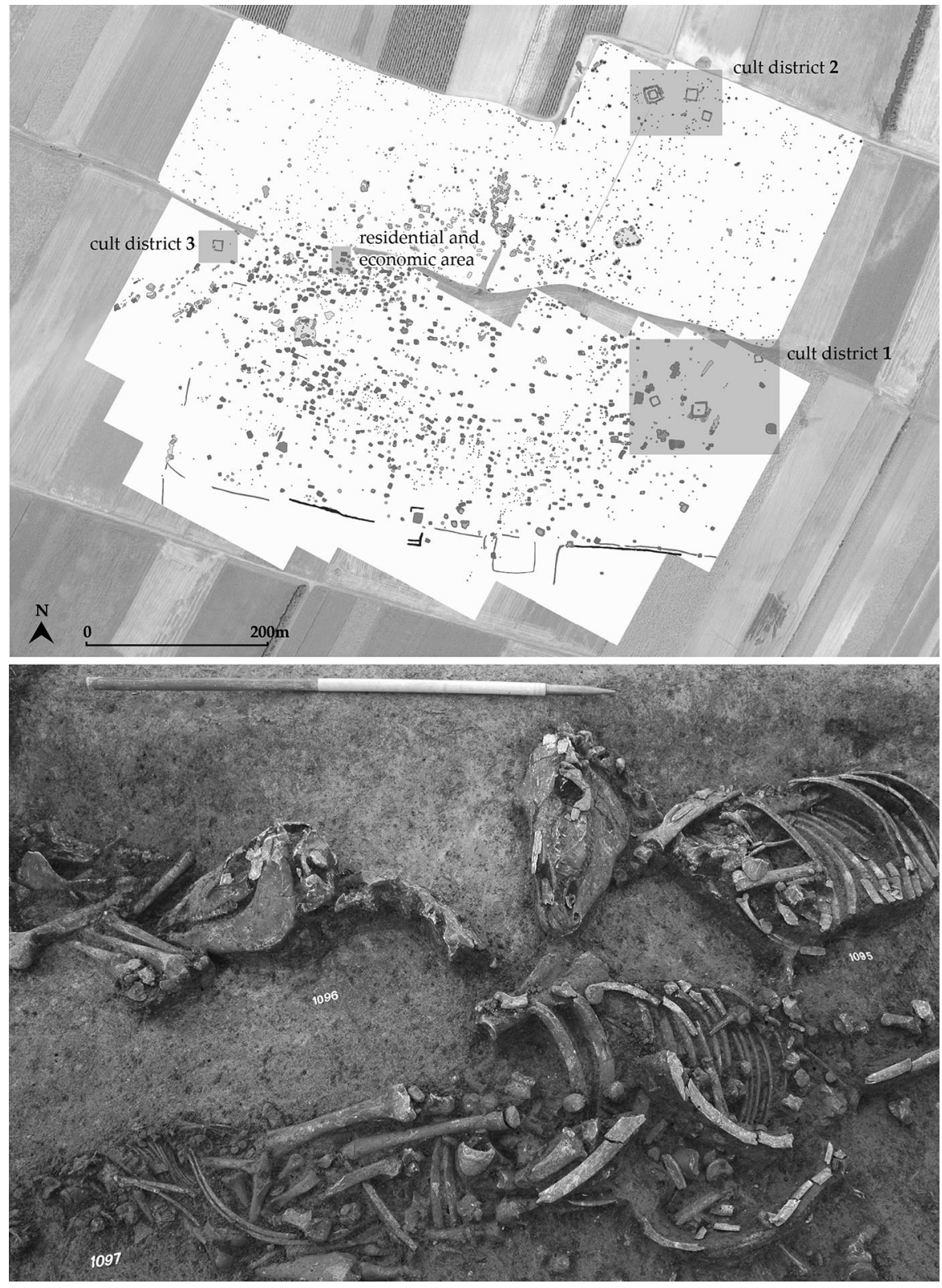

Fig. 7 Roseldorf: Interpreted geomagnetic plan of the settlement (above) and remains of horse sacrifices in one of the sanctuaries (below) (after Holzer 2014, modified by author)

Avaricum, Závist, Dünsberg, and the hilltop centers of the Middle Rhine-Moselle region. Despite the lack of clear settlement continuity, this makes it necessary to reconsider or at least qualify the traditional explanations about the genesis of these sites, placing them into a longue durée perspective and taking into consideration 


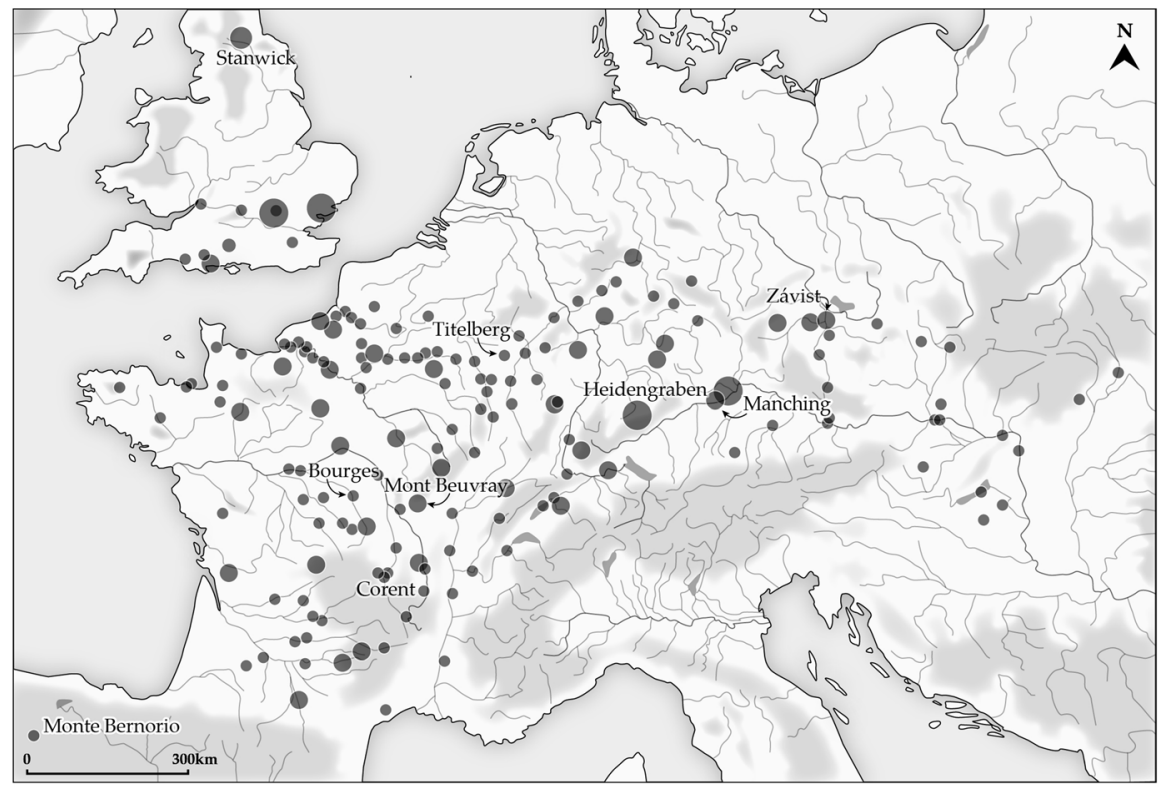

Fig. 8 Distribution of fortified oppida with indication of some of the main sites, second-first centuries BC (author, based on data from http://www.oppida.org/, with additions)

aspects such as collective memories and the establishment of links with the ancestral past (Fernández-Götz 2014a, c; Ramona 2011).

For the last stage of the Iron Age, our available sources increase considerably: coins proliferated and written accounts_-mostly Caesar's De bello gallico (1970)_ provide useful although biased insights into social organization, including descriptions of major settlements. Some oppida can be identified with names and even with events mentioned in written sources. To list only a few examples, Avaricum (Bourges) was besieged and captured by Caesar; Bibracte was the main center of the Aedui area and the location of the pan-tribal assembly at which Vercingetorix was proclaimed commander-in-chief of the confederation against the Romans; and Stanwick has been identified as the capital of Cartimandua, queen of Brigantes at the time of the Claudian invasion of Britain.

The Latin term oppidum (plural oppida) was used by Caesar to designate the main centers he encountered during the military conquest of Gaul; since the 19th century (Lukas 2014), it has become a sort of terminus technicus used by archaeologists to refer to large Late Iron Age fortified settlements with an area of at least 10 ha. However, behind this common terminology we need to acknowledge the existence of a heterogeneous reality (Woolf 1993). While some oppida were occupied only for one or two generations, others have relatively long histories. If some display characteristics that can be described as urban (e.g., Manching, Bibracte, Corent), others seem to have been nearly empty (e.g., Zarten/Tarodunum, Finsterlohr). Some were several hundred or even more than 1000 ha in size (e.g., Kelheim, Heidengraben), whereas others were no larger than 10 ha (e.g., 
Otzenhausen, Hrazany) (for a general overview of the data, see Fichtl 2005a, 2012a and the database http://www.oppida.org/).

Over and above this diversity, the most important common denominator of the oppida is their impressive fortification systems, which combined a defensive, ostentatious, and symbolic function (Fichtl 2010a; Ralston 2013). Walls and gates were emblems of community identity (Fichtl 2005b; Woolf 2006), and they also had a real military function of protection against potential threats (Armit 2007; Moret 2017). In addition, the monumental walls of the oppida (up to $7 \mathrm{~km}$ long at Manching and Bibracte) represent a significant labor investment and can be seen as the expression of a major communal effort. Their erection, and also regular maintenance, would have played an important role in the construction of collective identities (Rieckhoff 2014; Woolf 1993). Moreover, the frequent discovery of burials, animal bones, and deposits of objects such as coins or weapons inside or close to fortifications testifies to ritual practices and suggests that walls, ditches, and gates possessed a legal, political, and sacred significance (Nicolai 2014).

\section{Complex Settlement Landscapes: Assembling Fortified and Open Agglomerations}

The research of the last two decades has revealed an increasingly complex picture for the settlement landscapes of the last two centuries BC (Collis 2014; Kaenel 2006; Salač 2014). Until the 1980s, only the fortified oppida, mostly those located on mountains and prominent hills, were taken into account as major Late Iron Age centers. Today there is a growing awareness not only of the key role played by open agglomerations (Fichtl 2013; Haselgrove and Guichard 2013; Moore and Ponroy 2014) but also about the fact that a large number of oppida were located in lowlands. In order to acknowledge this complexity, new categories and classifications have been formulated, including the four distinctions proposed by Salač (2009): "centers of production and distribution," Lovosice being a typical example; "centers of the Němčice-Roseldorf type"; "mountain oppida" such as Bibracte, Donnersberg, and Heidengraben; and "lowland oppida" of which Manching is a prime example.

The latter site also exemplifies the diversity of settlement trajectories and the changing cycles of Late Iron Age urbanization (Fig. 9). While some large open sites were abandoned at the time of the foundation of the oppida (e.g., the transfer from the open settlement of Levroux, located on the plain, to a nearby hill; see Buchsenschutz et al. 2000), many others continued to exist. We also know of sites such as Manching in which an open agglomeration was fortified at a later stage of its history (Sievers 2007; Wendling 2013). Other open agglomerations such as Sources de l'Yonne, on the contrary, started at a relatively late stage in the immediate vicinity of an already existing oppidum like Bibracte. Going a step further, it is possible that both the fortified settlement on Mont Beuvray and the open agglomeration of Sources de l'Yonne were part of a single center and could be regarded as part of the same "Bibracte complex" (Moore et al. 2013). Enlarging perspectives also have been proposed for the three oppida of the Arverni in the basin of Clermont-Ferrand (Corent, Gondole, Gergovia), which could represent an 


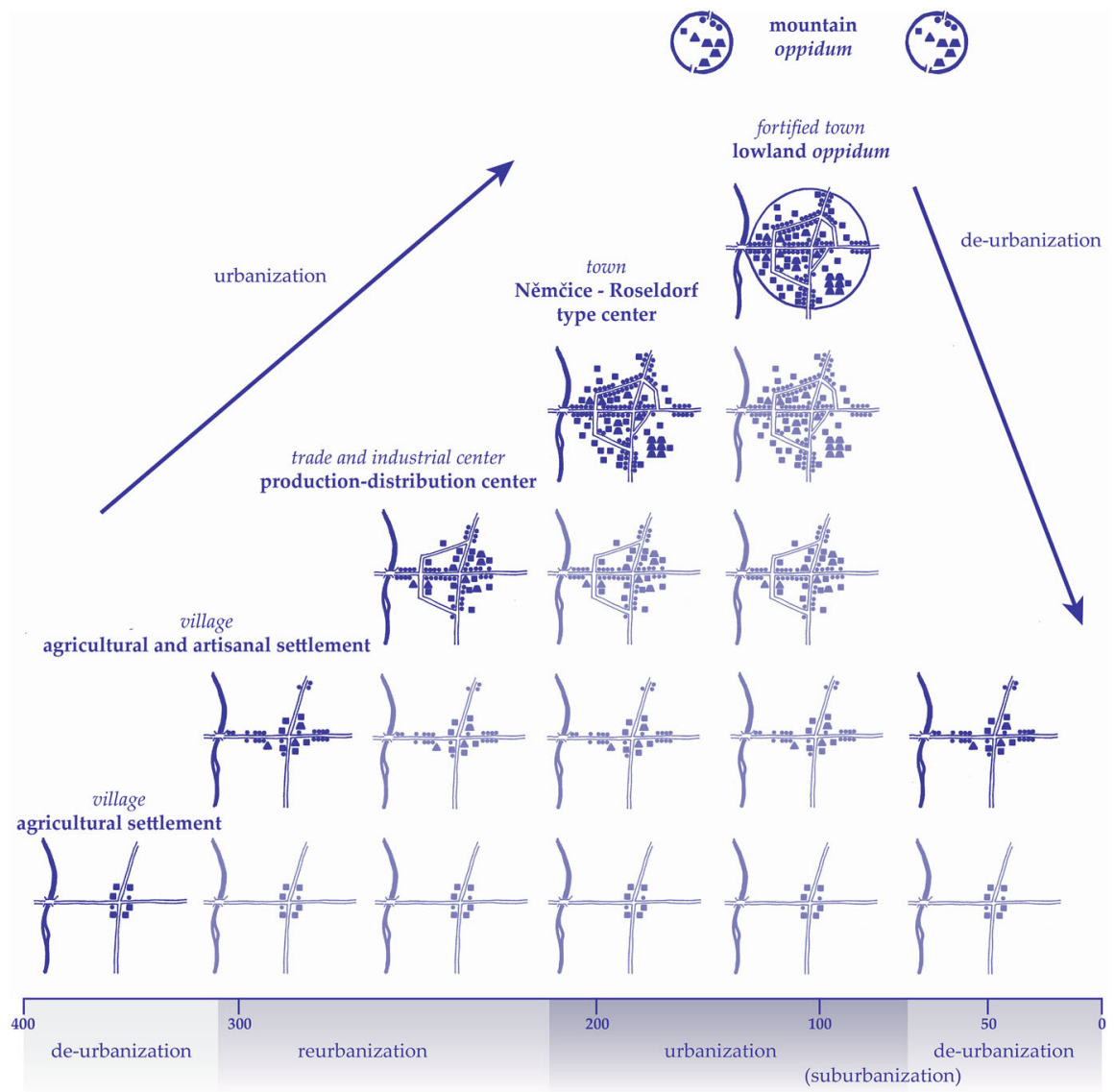

Fig. 9 Late Iron Age urbanization cycles (after Salač 2014, modified by author)

overlay of population clusters within a large, strongly urbanized area that spread over more than 2,500 ha (Poux 2014). Instead of a single fortified urban center, this example reveals the existence of a multipolar town pattern, raising completely new research questions and perspectives. The traditional tendency to prioritize enclosed sites may limit our appreciation of the nature of broader social change; open agglomerations and larger population clusters need to be increasingly considered when we discuss the origins and characteristics of urban development in Late Iron Age temperate Europe (Haselgrove and Guichard 2013; Moore and Ponroy 2014; Poux 2014).

Traditional approaches have emphasized the role of the oppida as the main centers of production and trade in the Late Iron Age, viewing them as a sort of proto-industrial cities and interpreting their functions and origins from predominantly economic perspectives (Collis 1984; Wells 1984). This assertion needs to be nuanced in light of recent research. While it is true that some oppida such as Manching, Stradonice, and Bibracte provide abundant evidence for specialized craft 
production (e.g., of pottery, glass, coins, and metalwork) as well as imported goods (Meylan et al. 2002; Wells 1996), others do not appear to have performed a significant economic role. The oppida were certainly complex central places that played a key role for Late Iron Age communities, but they did not monopolize largescale production or long-distance trade, since both also are attested in open agglomerations (Augstein 2006; Salač 2009, 2014). Mediterranean imports such as the widespread Roman amphorae, for example, also were present in large unfortified sites and sometimes even in small rural settlements and aristocratic residences in the countryside (Poux 2004).

On occasion, the number of characteristic Late Iron Age finds discovered at open agglomerations rivals or even exceeds those produced from the oppida, as demonstrated by Salač (2009, 2012): although it has not yet been excavated, some 518 glass bracelets have been found at the open site of Němčice, nearly as many as in the intensely excavated oppidum of Manching (620) and many more than in other important oppida like Stradonice (143) or Závist (4); some 1,500 coins have been found in Roseldorf, more than in Manching (1342), Staré Hradisko (91), or Závist (16). At the Bavarian open site of Berching-Pollanten, the range of objects found is not very different from that of the nearby and contemporaneous oppidum of Manching. This includes finds such as iron tools, fine pottery, glass bracelets, coins, keys, scales, and hundreds of brooches (Fischer et al. 1984; Schäfer 2010). In the second century BC virtually the same craft activities were apparently carried out in Berching-Pollanten as in Manching. The latter site was itself an open agglomeration of the Němčice-Roseldorf type until the construction of the murus gallicus in the second half of the second century BC (Sievers 2007; Wendling and Winger 2014).

Even if the symbolic and ostentatious role of fortifications should not be underestimated, we must question the notion that only fortified Iron Age centers can be classified as urban. The unfortified agglomerations of Manching or Roseldorf most likely deserve that term, whereas some fortified oppida such as Mont Vully, Zarten/Tarodunum, and Finsterlohr seem to have been enormous fortified enclosures with virtually no sign of any internal occupation. Finally, as mentioned above, there were sites like Bibracte/Sources de l'Yonne in which both a large fortified center and an open agglomeration coexisted in close proximity for a certain period of time and can perhaps even be regarded as part of the same urban complex (Moore et al. 2013; Moore and Ponroy 2014).

\section{Endogenous Factors and External Influences}

The early chronology of the above-described open agglomerations, with their important evidence of commercial and artisanal activities, has important consequences for our understanding of Late Iron Age urbanization processes in temperate Europe. From France to Hungary, in most regions the concentration of the population and economic activities began several generations before the foundation of the oppida (Collis 1995; Fichtl 2013; Kaenel 2006). Moreover, the idea that there was a decisive urbanizing impulse that originated in Cisalpine Gaul can no longer be sustained (Kysela 2009). Therefore, the emergence of Late Iron Age urbanism can primarily be explained on the basis of complex endogenous factors, which 
would include, among others, demographic growth and a resurgence of social hierarchization that was favored by a period of warmer climate and the improvement of production techniques. Both the beginning of the new trend toward centralization and the intensification of production occurred some considerable time before Rome's conquest of southern Gaul in the $120 \mathrm{~s} \mathrm{BC}$.

This latter historical event, its aftermath in the form of increasing pressure from the Roman world, and the raids of the Cimbri and the Teutones all could have influenced-directly or indirectly - the widespread phenomenon of fortification that took place toward the end of the second century BC. In the last decades of that century, there was large-scale establishment of new fortified nuclei (the oppida) and even the construction of artificial defenses around some of the existing open centers. Moreover, the process of urbanization was accelerated (although not started!) by increasing trade with the Roman world, as attested by large numbers of imports from the south and the establishment in parts of Gaul of the so-called zone du denier gaulois, an area with silver coins of similar standards designed to facilitate exchange with Rome. But the external factors - as important as they might have been - can be understood only in combination with internal trends, particularly the articulation of political control in a framework of growing socioeconomic complexity.

Approaching the origins of major Late Iron Age settlements from a paths-tocomplexity perspective, it is possible to state that most open agglomerations developed over time as the result of organic growth and with an important bottomup component (Buchsenschutz 2015; Salač and Buchsenschutz 2014). In contrast, the majority of oppida were founded as the result of deliberate political decisions that often involved processes of synoecism directed from the top-down by the powerful aristocratic families that in areas like Gaul dominated the political life of the last stages of the Iron Age (Buchsenschutz and Ralston 2012; Gruel and Buchsenschutz 2015; Verger 2009). Thus, with few exceptions, the oppida were deliberate foundations rather than the result of a gradual evolution (Collis 2000; Fichtl 2005a). If we adopt a Foucaultian perspective (Foucault 1980), these fortified settlements represented a new "technology of power" that enabled a more hierarchical and centralizing ideology to be articulated (Fernández-Götz 2014a, c). From this point of view, their appearance also can be seen as a way of reinforcing social cohesion and political control; the oppida are the expression of more unequal societies and at the same time contributed to the construction of those inequalities (Brun 2001; Rieckhoff 2014). Their internal structure usually indicates previous planning and a manifestation of the principles of social order that govern communities (Fernández-Götz 2014c), including the large-scale proliferation of linear structures (Sievers 2006, 2012).

\section{Open Urban Spaces: Plazas and Assemblies}

As noted by Fletcher (2007), the oppida fit well into the notion of low-density urbanism. They enclose large areas but generally present a low population density per hectare. Thus the above-mentioned figures of 5,000-10,000 inhabitants proposed for both Manching and Bibracte would result in a population density of 
13-26 inhabitants per hectare in the case of Manching (380 ha) and 37-74 for the second fortification phase of Bibracte (135 ha). This means that even these and other oppida that present a significant internal occupation also include large free areas inside the fortified space. The layout of the walls often was determined by the local topography, but in addition the "empty spaces" (Smith 2008) could serve a variety of economic and social purposes, from areas for agriculture and cattle breeding to places for assembly and refuge of the rural population in case of danger. The recurrent existence of large open areas within the oppida suggests that these unoccupied spaces were, in fact, one of their principal elements, playing a fundamental role in the negotiation of control over people and resources. This would have included the periodic assembly of the dispersed rural population (see below). Rather than interpreting the existence of open spaces and low-density occupation as an indication for "unfinished" urban places, we should recognize that they constitute a defining characteristic of many major settlements. Urban open spaces are widely found in both ancient and modern urbanism (Stanley et al. 2012; Woolley 2003), so that their presence in the oppida does not contradict the urban character of at least some of these sites.

Another key feature of many Late Iron Age centers-oppida, but sometimes also open agglomerations-is that the basic settlement units were enclosed farmsteads that resemble rural settlement types. The term "rurban'" (Smith 1972) encapsulates the idea of the domination of these sites by unbuilt space more similar to farm landscapes than our traditional notions of urban quarters. These groups of farms with their outbuildings indicate the transfer of rural settlement patterns to a more confined area, in other words a kind of "translocated landscape" with clustered extended households that could occasionally also perform artisanal and commercial functions (Fig. 10). This phenomenon is similar to the pattern already observed centuries earlier in the outer settlement of the Heuneburg agglomeration (see above); it suggests the nucleation of part of the rural population and a concentration of activities that were previously dispersed more widely on the landscape (Danielisová 2014; Woolf 1993). But the large settlements were more than a simple collection of farms; their population would have included nonproducers (e.g., full-time specialists and, particularly in the case of the oppida, elite members and religious specialists), and we often know about the existence of different functional zones and neighborhoods such as in Manching (Sievers 2007) and Corent (Poux 2012). Finally, an increasing number of public spaces for religious and political gatherings have been identified over the last few decades within the oppida.

This latter aspect is one of the most important advances in recent research. The discovery of public spaces and sanctuaries at sites such as Manching, Titelberg, Martberg, Bibracte, and Corent provides evidence for the political and religious life of Late Iron Age communities, constituting a prime example of the important political and religious role of the oppida (Fernández-Götz 2014c; Fichtl 2010b, 2012d; Metzler et al. 2006, 2016). These public spaces were fundamental arenas for interaction and collective negotiation, comparable in their functions to the plazas known in other parts of the world such as Mesoamerica (Tsukamoto and Inomata 2014) and the Andean region (Moore 1996). 


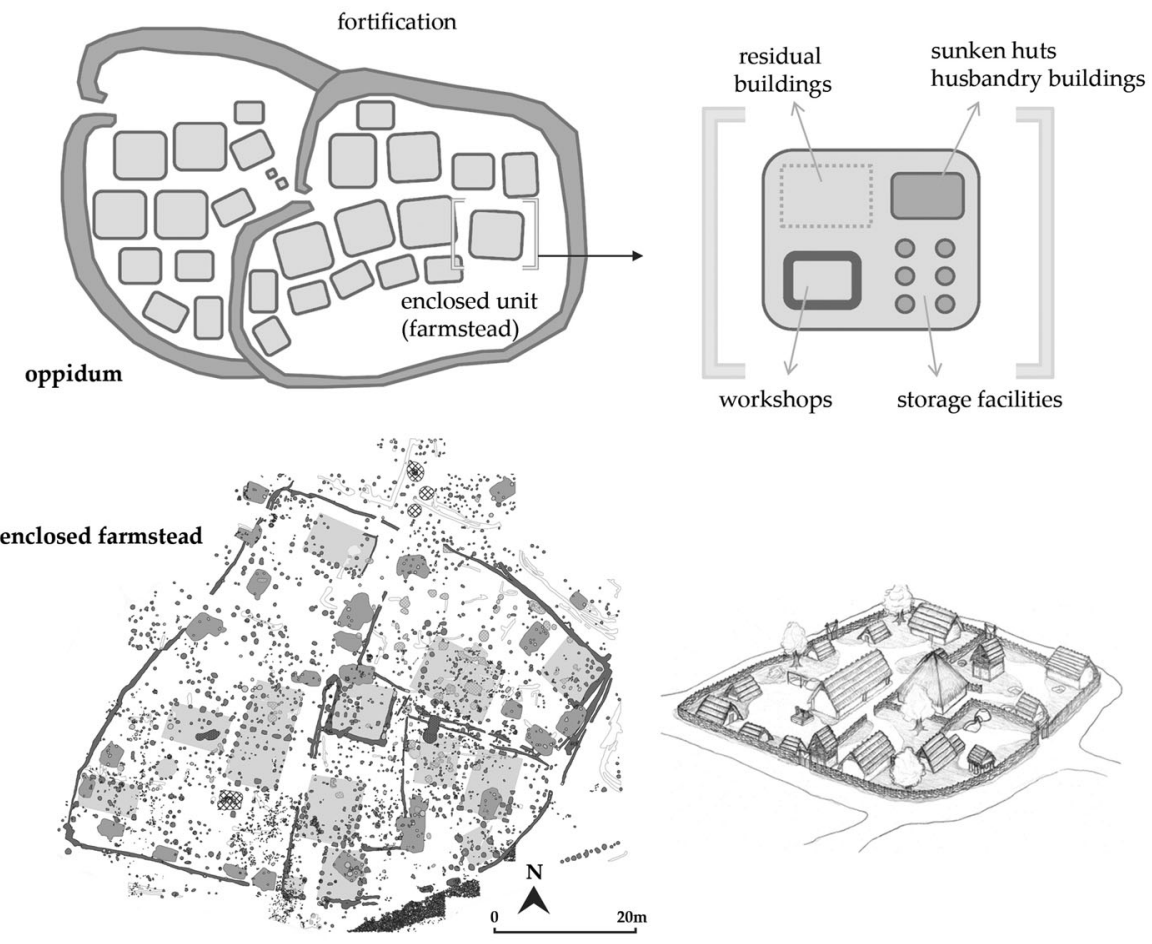

Fig. 10 Internal structure of the oppida (after Danielisová 2014)

The oppidum of Titelberg in Luxembourg is particularly interesting. The presence of more than 5,000 Celtic coins, Mediterranean imports such as Dressel 1 amphorae, Campanian pottery, and Italic bronze vessels attests to the prosperity of this site. There is also strong evidence of different activities involving artisan crafts on a scale that went beyond supplying local needs, notably iron and bronze working and the minting of coins (Metzler 1995). However, the most outstanding feature is the so-called public space or area sacra where assemblies, fairs, and religious ceremonies were held (Metzler et al. 2016). This was a large area covering 10 ha in the eastern part of the oppidum, surrounded by a ditch, which contained evidence for ritual activities, and a mud-brick wall. Voting installations of the first half of the first century BC provide evidence for political decision making within the public space, and the enormous number of documented animal bones points to large-scale communal feasting (Fernández-Götz 2014d; Metzler et al. 2016).

At least in the first century BC, Titelberg seems to have been the main center or capital of the tribal polity of the Treveri. Although its public space is exceptionally large (10 ha) and potentially able to accommodate a large public assembly such as that described by Caesar for the Treveri (De bello gallico, book V, section 56), it is certainly not the only Treveran oppidum that shows traces linked to gatherings and cult activities. Indeed, spaces for religious practices and assemblies have been archaeologically identified in six of the seven Treveran oppida, at the highest point 
in the five oppidum-Titelberg, Martberg, Wallendorf, Otzenhausen, and KastelStaadt (Fernández-Götz 2014d; Metzler et al. 2006).

Written sources, particularly Caesar, describe the existence of political institutions such as public assemblies and senates among temperate European societies (Fernández-Götz 2014a), and it seems that many oppida acted as locations for those political bodies. Several passages in De bello gallico (e.g., book VII, sections 33, $55,63)$ mention the celebration of large assemblies and council meetings within the oppida; the fact that Caesar's military strategy was often aimed at obtaining the submission of a whole tribal polity by conquering a major oppidum also underlines the role of these settlements as political centers. As mentioned above, archaeological research also is uncovering a growing number of public spaces or plazas and even buildings that could have served for political meetings; one example is the presumed meeting place of the Arvernian senate recently discovered at the public square of Corent in close proximity to the central sanctuary and the market place (Fig. 11; see Poux 2012; Poux and Demierre 2016). The enormous quantity of animal bones found at sites such as Titelberg, and the large number of wine amphorae documented at places like Bibracte and Corent, provides evidence for communal festivals and banquets, probably linked to political assemblies, religious celebrations, and fairs (Fernández-Götz 2013; Poux 2004). Cross-cultural studies of feasting and commensality have emphasized the importance of collective eating and drinking as major means for establishing and reinforcing the social order, and for defining group membership (Dietler and Hayden 2001; Hayden 2014).

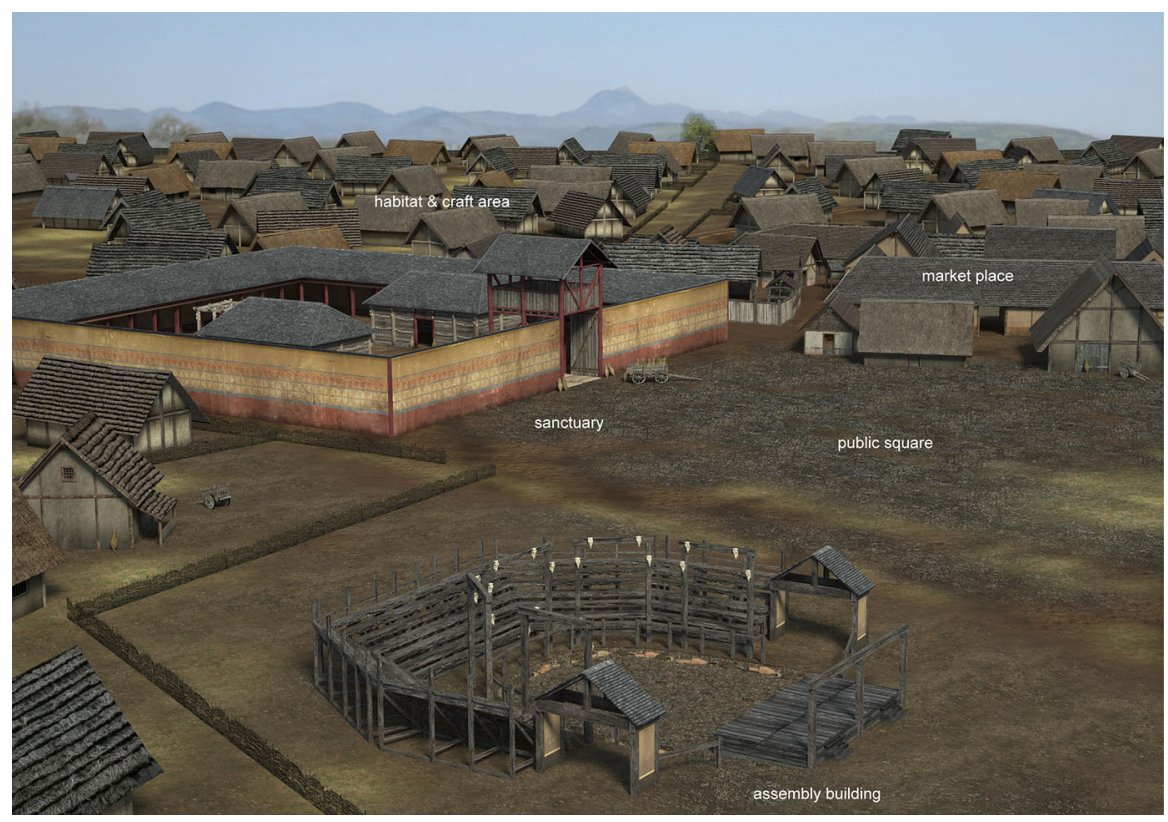

Fig. 11 Idealized reconstruction of the center of the oppidum of Corent with main public structures (after Poux 2014) 
In this sense, the primary role of the oppida would have been to serve as central places for the tribal and subtribal polities of the Late Iron Age (Collis 2007; Fichtl $2012 \mathrm{~b}$ ), representing focal points of politico-religious aggregation and negotiation (Fernández-Götz 2014c). The number of people that lived permanently within the oppida would have been less important than the function of these centers as objects of identification for larger groups. In a world where the immense majority of the population continued to live dispersed in the countryside (Buchsenschutz 2006; Malrain et al. 2002), the oppida served as focal points of reference that were periodically visited by inhabitants of the rural hinterland on the occasion of markets, political celebrations, religious festivals, and also as places of refuge during times of conflict. The public gatherings and celebrations held at the oppida must have been key elements in the fostering of social cohesion, self-awareness, and shared identity (Fernández-Götz and Roymans 2015; Gerritsen and Roymans 2006). Public assemblies in particular were important mechanisms of collective governance, similar to those existing in societies all around the globe (e.g., Blanton and Fargher 2008). They represent early arenas for political debate, conflict resolution, alliances, and the display of power, and were therefore important tools for the functioning of communities (Fernández-Götz 2013; Sanmark et al. 2015-2016). Although these political institutions were to a certain extent instrumentalized and controlled by members of the Late Iron Age elite through their clientage networks, they also limited the agency of the aristocratic classes and redistributed social power.

Smith (2016) has recently stated that most premodern cities were political cities in which the role that clearly predominates is the political, not the economic; the oppida seem to fit well within this model. This is not to deny the economic role of many of these centers but to reconsider the weight given to the different components. In cases where a significant economic activity can be observed, this seems to have developed as a consequence or by-product of the political and religious significance of the sites.

\section{The Sacrality of Place: Space and Memory in Urban Choice}

Going a step further, it is possible to propose that many oppida had their origin in spaces for ritual gatherings (Fernández-Götz 2014a, c; Fichtl et al. 2000; Metzler et al. 2006). In temperate Europe, there are various examples of oppida where a place for cult activities and/or assemblies preceded the concentration of a significant number of people or even the fortification of the area, a phenomenon that is particularly evident in Manching (Sievers 2007; Wendling 2013). At the center of this oppidum was temple A, the first phase of which dates back to the end of the fourth century BC. Nearby was a paved space covering an area of $50 \times 80 \mathrm{~m}$ that may have been used as a meeting place and several votive deposits of materials dating from between the fourth and second centuries BC. At the Gallic oppida of Corent and Moulay, the excavations have proven that the sanctuaries were founded before the development of the settlements (Fichtl et al. 2016; Poux and Demierre 2016), whereas in Bibracte isotopic and dendrochronological dating suggest that the public space known as La Terrasse-measuring 110 x $92 \mathrm{~m}$ and situated near a Gallo-Roman temple - could have been established already in the third century BC 
(Fleischer and Rieckhoff 2002). Gournay-sur-Aronde is also revealing, because although the origin of the famous sanctuary is in the fourth-third century BC, the oppidum itself did not develop until well into the first century BC (Brunaux et al. 1985). This phenomenon was not restricted to temperate Europe, since a similar situation was present in southern Gaul at Iron Age sites such as Entremont or Glanum, where the sanctuaries originated earlier than the oppida (Garcia 2006). In the northwestern Iberian Peninsula, San Cibrán de Lás provides an exceptional example of sacrality in the longue durée from several centuries before the foundation of the oppidum (Álvarez-González et al. in press).

The above-mentioned examples show that, in many cases, the use of a place for cult purposes and holding assemblies would have been the cause, and not the consequence, of the development of oppida at these sites. Although there would have been exceptions to this model, the recognition that in several cases open assembly spaces developed early, and then other urban functions came later, has important implications for our understanding of centralization processes and the dynamics of collective aggregation. The oppida are the result of socioeconomic processes related to demographic growth and increasing complexity, but the choice of place was often determined by earlier religious considerations and collective memories. In a context of population increase, growing production, and the flourishing of contacts with the Mediterranean world, religion must have been the principal cohesive force through which the integration of Late Iron Age communities into broader sociopolitical groupings was structured (see Feinman 2016 for the role of rituals as mechanisms of sociopolitical integration).

Following on from this, the location of a whole series of hilltop sites and oppida such as Bibracte, Heidetränk, and Ulaca can be explained only on religious or symbolic grounds. Contrary to what is often claimed, there is a whole series of oppida, mostly mountain oppida, whose choice of site cannot be understood solely on the basis of what we would consider "rational" parameters, such as a position that provides easy access to the main long-distance trade routes or economic potential in the immediately surrounding area. Bibracte is a good example; without denying the existence of certain economic and strategic components, the site is on a mountain that is part of the Morvan massif and its position is not ideal for trade, agriculture, or as a place to live, particularly in long and cold winters. What seems clear is that ritual considerations need to be taken increasingly into account to address the origins, trajectory, and heterogeneity of the oppida (Fernández-Götz 2014c; Metzler et al. 2006; Wells 2006).

This model of oppida developing at places that already enjoyed a sacred connotation also has been suggested for several of the large "territorial oppida" in Britain, numbers of which potentially originated at periodically used meeting places (Haselgrove 2000). The Late Iron Age oppida of southern Britain as well as Stanwick to the north share some characteristics with their continental counterparts (Haselgrove 2016; Pitts 2010; Sharples 2014). An exceptional example is the early harbor site of Hengistbury Head (Cunliffe 1978). Due to the later conquest of the island by the Romans, oppida developed there until well into the first century AD (Cunliffe 2005), and central places such as Stanwick (Haselgrove 2016) and Bagendon (Moore 2014) could have acted as tribal capitals at the time of the 
Claudian invasion. A remarkable group of British settlements are the so-called "polyfocal oppida complexes" like Verulamium, Bagendon, and Colchester/ Camulodunum, characterized by massive earthworks that often stretch for many kilometers and encompass huge areas of landscape (Moore 2012); the inner area of some of these sites is perfectly comparable or even exceeds the largest examples on the continent.

Oppida also developed in the interior and northern regions of the Iberian Peninsula, but their chronology is somewhat different from the major sites north of the Pyrenees (Almagro-Gorbea 1995; Álvarez-Sanchís et al. 2011). Generally, they present a longer historical trajectory that can sometimes be traced back to the Early Iron Age or even to the Late Bronze Age, as in the oppidum of Monte Bernorio in northern Spain. Settlement on the impressive mountain of Monte Bernorio started in the ninth-eighth centuries BC and apparently developed continuously until the violent destruction of the site by the Roman army at the end of the first century BC (Torres-Martínez et al. 2016) (Fig. 12). In the last stages of the Iron Age, the upper part of Monte Bernorio was fortified by a rampart and a ditch that enclosed an area of about 28 ha, but a multivallate fortification system of large concentric earthen ramparts expanded the total area to around 90 ha. In the second-first centuries BC, the oppidum of Monte Bernorio shows many similarities with contemporaneous sites in Gaul and central Europe. However, its dimensions remain rather exceptional for the Iberian Peninsula, where the immense majority of fortified sites were considerably smaller than their central European counterparts (Almagro-Gorbea and Dávila 1995).

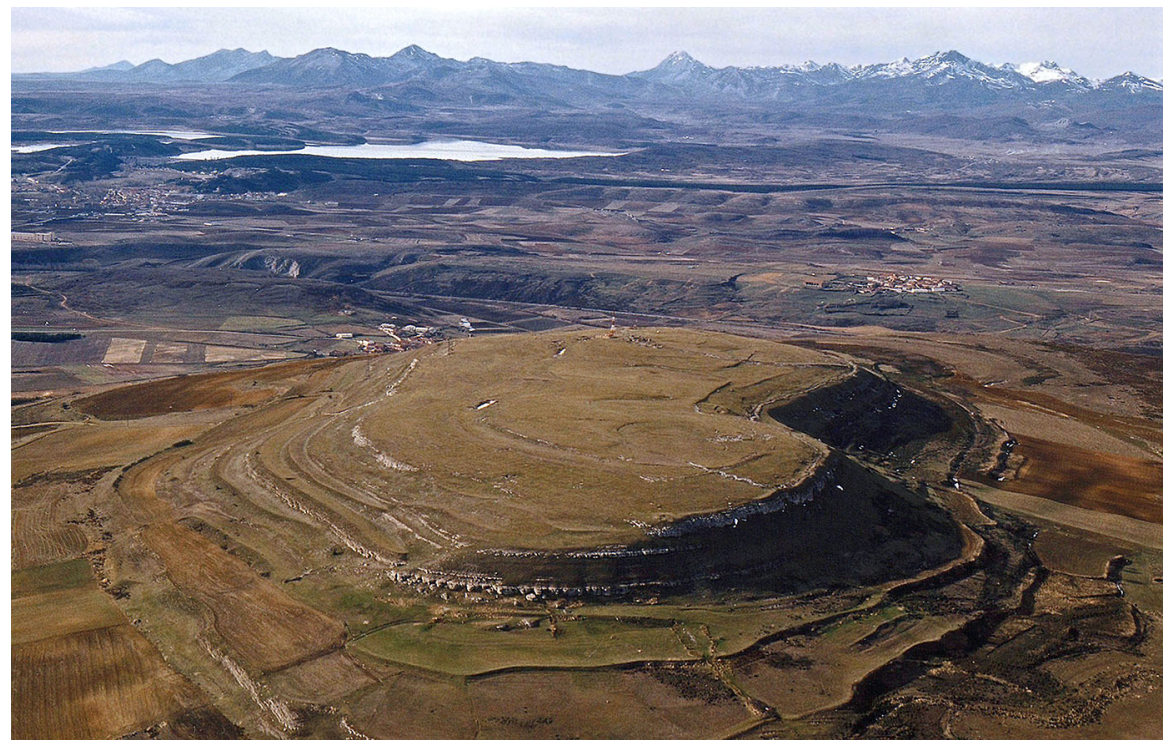

Fig. 12 Aerial photography of the Bernorio mountain at the foothills of the Cantabrian Mountains. (C) IMBEAC) 
With the exception of the oppida of southern Gallaecia in the northwest, in northern Spain Iron Age settlement patterns are dominated by small hillforts (castros) of only a few hectares (Almagro-Gorbea 2002). On the other hand, some large oppida developed in central Spain, particularly in the territory of the Vaccei and the Vettones (Álvarez-Sanchís 2005; Álvarez-Sanchís et al. 2011; RuizZapatero and Álvarez-Sanchís 1995). Among the latter, the impressive mountain oppidum of Ulaca probably acted as the main tribal center; its religious significance is highlighted by a remarkable rock sanctuary and a ritual sauna (Ruiz-Zapatero 2005). In the territory of the Celtiberians of the eastern Spanish uplands (Meseta), some powerful city-states developed in the second century BC, above all Segeda. This city minted its own coinage and initiated a process of synoecism that was interrupted by the war with Rome (Burillo-Mozota 2014).

\section{Urbanization and Imperial Power}

In most areas of temperate Europe the end of the oppida is related to the Roman conquest, which took place between the early second and the late first centuries BC in central-northern Iberia, from 58 to $51 \mathrm{BC}$ in Gaul, and from AD 43 in Britain. This general explanatory framework does not apply, however, to most regions east of the Rhine; the decline of the large oppida of southern Germany took place several decades before the Roman conquest, so that earlier interpretations that associated the end of Manching with the Alpine campaign of Drusus and Tiberius in 15 BC have been discarded. The existence of a population hiatus has been proposed for southern Germany, and although this may not have been a complete depopulation, the Roman urban settlement patterns show little to no relationship with the previous Late Iron Age occupation. In these regions, as well as in central Germany and the Czech Republic, the abandonment of the oppida in the course of the first century BC could have been related to the arrival of new populations from southern Poland and eastern Germany in the context of the historically documented migrations of "Germanic" groups (Rieckhoff 1995; Salač and Bemmann 2009; Wigg 1996).

Be that as it may, in most regions incorporated into the Roman Empire the military conquest did not automatically cause the end of the oppida (Collis 1984; Fichtl 2005a). Although there are examples of violent destruction of sites such as Monte Bernorio, the majority of the oppida were not abandoned during or immediately after the Roman conquest. In fact, many Gallic oppida experienced a period of flourishing in the decades between 60 and $20 \mathrm{BC}$, as exemplified by the construction at Bibracte of rich aristocratic domus and a basilica following Roman prototypes (Rieckhoff et al. 2009; Szabó et al. 2007). However, a major break can be observed in Augustan times, with the abandonment of numerous oppida and the decline of other ones. In any case, there also are some examples of long-term continuity.

In summary, three different outcomes can be distinguished for the oppida after the Roman conquest: the conversion of an oppidum to an important Roman city on the same site, sometimes being continuously inhabited up to present times (e.g., Besançon, Bourges); the conversion of an oppidum into a secondary agglomeration of variable size and importance, but with a decline in importance; and the 
abandonment of the oppidum in favor of a Roman city normally situated on the plain, as in the archetypal case of the replacement of Bibracte by Autun in central France or the move from Ulaca to Ávila in central Spain.

A final aspect that deserves consideration is the fact that the frontiers of Rome's expansion in central and northwestern Europe largely coincide with the distribution area of Late Iron Age oppida. Although each regional scenario presents its own characteristics, a macroscale perspective reveals the importance of the pre-Roman background; those areas with an existing tradition of social and territorial organization structured around large central places were easier to integrate and control than others with more decentralized patterns such as Germania and Scotland. Mutatis mutandis, a comparison can be drawn with other scenarios of imperial conquest around the world; thus for the Spanish conquistadors in the Americas it was much easier to establish effective control over developed state formations than over dispersed tribal societies such as the Mapuche populations in Chile (Cruz 2010).

\section{Concluding Remarks: Grand Narratives and Future Challenges}

Iron Age urbanization processes were nonlinear, multilayered phenomena that involved different cycles of centralization, decentralization, and reurbanization. Two main cycles of urbanization can be distinguished north of the Alps, the first in the sixth and fifth centuries $\mathrm{BC}$ and the second between the late third and the first centuries BC. Although the Late Iron Age oppida present a much wider geographical distribution and generally also larger inner areas as the Early Iron Age "Fürstensitze," the differences between both types of settlements are less marked than traditionally thought. In contrast to the situation observed in some areas in the Mediterranean Basin, where centers often developed gradually throughout the course of the first millennium BC (e.g., Gadir, Carthage, Athens, Rome), in central Europe settlement trajectories were characterized by a high degree of discontinuity. Early cities were a new and crucial element in the Iron Age, but they remained the exception rather than the rule in the landscapes of temperate Europe. Even during the periods of urbanization, the immense majority of the population continued to live in rural farmsteads and hamlets, and there also are many regions in which urban sites never developed. We have to acknowledge the existence of a multidimensional reality with a high degree of synchronic and diachronic variability. Together with hierarchically organized societies such as those described for the "Fürstensitze," there also were other communities in which the structures of power were less clearly defined and that present evidence for a more heterarchical and decentralized social landscape (Hill 2006).

From a grand narrative perspective, demography and climate change are among the most important factors that seem to have driven social transformations in the temperate European Iron Age; external influences by other cultures also figure prominently, although not in the simplistic and unidirectional way proposed by some traditional Mediterraneo-centric perspectives. Demographic growth, at many times favored by climatically warmer periods, would have intensified pressure 
on resources and generated an increase in social density, that is, the frequency of communication and interaction occurring between individuals and groups through their social, political, and economic networks (e.g., Lawrence et al. 2016; Ortman et al. 2014). This, in turn, would have stimulated social hierarchization and processes of settlement nucleation (aggregation and urbanization) that reached their peak at the time of the "Fürstensitze" and the oppida. From this perspective, late prehistoric centralization processes also can be understood as triggers of social control, in the sense that the concentration of people at one place enables a greater degree of control over them (Müller 2016). At the same time, principles of moral economy designed to limit the concentration of power in the hands of single individuals or families would have been in operation (Fernández-Götz 2014a; González-Ruibal 2012; Hill 2006). The dialectical tensions between trends toward increased centralization, hierarchization, and control versus heterarchical ideologies that emphasize self-government and isonomy must have played a key role in at least some of the episodes of aggregation and disruption that we observe in the archaeological record. Thus, although demography and climate are rightly highlighted in long-term macroregional perspectives (e.g., Cunliffe 2015), the correlation between them and a variety of other factors (both geographical and societal) was neither teleological nor linear, making it necessary to acknowledge that "equivalent increments in size do not have uniform cross-cultural effects on organization" (Feinman 2013, pp. 40-41).

As seen in the course of this article, the research of the last few decades has expanded our knowledge enormously. This is particularly true regarding the Early Iron Age "Fürstensitze" and the Late Iron Age open agglomerations but also the genesis of the oppida and their political and ritual significance. The picture that emerges is much more complex and dynamic than traditionally thought, and it can be expected that the large-scale application of LIDAR images, drone flights, and geophysical surveys will continue to significantly expand the corpus of known sites and our understanding of their functions and internal organization. Whereas the number of mountain oppida will probably not experience any notable variation, the number of lowland oppida and open agglomerations will certainly grow exponentially. An aspect that deserves particular attention is the interrelationship between urban centers, small rural settlements (farmsteads, hamlets), and the environment. From a theoretical perspective, the application of comparative approaches is still embryonic and should be expanded in coming years. Such an approach would allow archaeologists working on Iron Age Europe to draw on the rich variety of concepts and insights of comparative urban studies. Placing the development of urban centers in Iron Age Europe into the broader field of comparative urbanism remains one of the main challenges for future research. The journey has just started, but it is a promising one.

Open Access This article is distributed under the terms of the Creative Commons Attribution 4.0 International License (http://creativecommons.org/licenses/by/4.0/), which permits unrestricted use, distribution, and reproduction in any medium, provided you give appropriate credit to the original author(s) and the source, provide a link to the Creative Commons license, and indicate if changes were made. 


\section{References Cited}

Abels, B.-U. (2005). Die Ehrenbürg bei Forchheim, die frühlatènezeitliche Mittelpunktsiedlung Nordostbayerns. In Biel, J., and Krausse, D. (eds.), Frühkeltische Fürstensitze: Älteste Städte und Herrschaftszentren nördlich der Alpen? Archäologische Informationen aus Baden-Württemberg 51, Esslingen, pp. 42-47.

Abels, B.-U. (2010). Die Ehrenbürg bei Forchheim: Die frühlatènezeitliche Zentralsiedung Nordostbayerns. In Krausse, D. (ed.), "Fürstensitze” und Zentralorte der frühen Kelten, Teil I: Forschungen und Berichte zur Vor- und Frühgeschichte in Baden-Württemberg 120/1, Stuttgart, pp. 101-128.

Alexander, J. (1972). The beginnings of urban life in Europe. In Ucko, P., Tringham, R., and Dimbleby, G. W. (eds.), Man, Settlement and Urbanism, Duckworth, London, pp. 843-850.

Almagro-Gorbea, M. (1995). From hill-forts to Oppida in 'Celtic' Iberia. In Cunliffe, B., and Keay, S. (eds.), Social Complexity and the Development of Towns in Iberia: From the Copper Age to the Second Century AD, British Academy, London, pp. 175-207.

Almagro-Gorbea, M. (2002). Urbanismo y sociedad en la Hispania húmeda. In de Blas, M. A., and Villa, A. (eds.), Los poblados fortificados del noroeste de la Península Ibérica: formación y desarrollo de la cultura castreña, Ayuntamiento de Navia, Navia, pp. 47-80.

Almagro-Gorbea, M., and Dávila, A. F. (1995). El área superficial de los oppida en la Hispania céltica. Complutum 6: 209-233.

Álvarez-González, Y., López-González, L., Fernández-Götz, M., and García-Quintela, M. V. (in press). El oppidum of San Cibrán de Las y el papel de la religión en los procesos de centralización en la Edad del Hierro. Cuadernos de Prehistoria y Arqueología de la Universidad Autónoma de Madrid (CUPAUAM).

Álvarez-Sanchís, J. R. (2005). Oppida and Celtic society in western Spain. E-keltoi 6 (special issue: The Celts in the Iberian Peninsula): 255-285.

Álvarez-Sanchís, J. R., Jimeno, A., and Ruiz Zapatero, G. (eds.) (2011). Aldeas y ciudades en el primer milenio a.C. La Meseta Norte y los orígenes del urbanismo, Complutum 22(2), Universidad Complutense, Madrid.

Álvarez-Sanchís, J. R., and Ruiz-Zapatero, G. (2014). The emergence of urbanism in Early Iron Age central Iberia. In Fernández-Götz, M., Wendling, H., and Winger, K. (eds.), Paths to Complexity: Centralisation and Urbanisation in Iron Age Europe, Oxbow Books, Oxford, pp. 204-213.

Arcelin, P., and Brunaux, J.-L. (eds.) (2003). Cultes et sanctuaires en France à l'Âge du Fer, Gallia 60, Nanterre.

Armit, I. (2007). Hillforts at war: From Maiden Castle to Taniwaha Pā. Proceedings of the Prehistoric Society 73: 25-37.

Augier, L., Buchsenschutz, O., and Ralston, I. (eds.) (2007). Un complexe princier de l'âge du Fer: L'habitat du promontoire de Bourges (Cher) (VIe-IVe s. av. J.-C.), Bituriga, Bourges.

Augier, L., Buchsenschutz, O., Durand, R., Filippini, A., Germinet, D., Levéry, M., Maçon, P., Pescher, B., Ralston, I., Salin, M., and Troadec, J. (2012). Un complexe princier de l'âge du Fer: le quartier artisanal de Port Sec sud à Bourges (Cher), Bituriga, Bourges.

Augstein, M. (2006). Handel und Handwerk: Überlegungen zur wirtschaftlichen Grundlage offener Siedlungen der Mittel- und Spätlatènezeit. In Wotzka, H.-P. (ed.), Grundlegungen: Beiträge zur europäischen und afrikanischen Archäologie für Manfred K. H. Eggert, A. Francke Verlag, Tübingen, pp. 595-606.

Baitinger, H. (2010). Der Glauberg: ein Fürstensitz der Späthallstatt-/Frühlatènezeit in Hessen, Materialien zur Vor- und Frühgeschichte von Hessen 26, Wiesbaden.

Baitinger, H., and Pinsker, B. (eds.) (2002). Das Rätsel der Kelten vom Glauberg: Glaube - Mythos Wirklichkeit, Konrad Theiss Verlag, Stuttgart.

Biel, J. (2015). Hochdorf IX: Die eisenzeitliche Siedlung in der Flur Reps und andere vorgeschichtliche Fundstellen von Eberdingen-Hochdorf (Kreis Ludwigsburg), Forschungen und Berichte zur Vorund Frühgeschichte in Baden-Württemberg 111, Darmstadt.

Birch, J. (ed.) (2013). From Prehistoric Villages to Cities: Settlement Aggregation and Community Transformation, Routledge, New York.

Blanton, R. E., and Fargher, L. F. (2008). Collective Action in the Formation of Pre-Modern States, Springer, New York.

Bourgeois, J., Mulder, G. de, and Putman, J.-L. (eds.) (2006). The Kemmelberg and Related Elite Sites in Central and Western Europe (6th-5th Century): Perspectives for Future Research, VIOE, Brussels. 
Brunaux, J.-L., Méniel, P., and Poplin, F. (1985). Gournay I: les fouilles sur le sanctuaire et l'oppidum (1975-84), Revue Archéologique de Picardie, n sp., Amiens.

Brun, P. (1995). Oppida and social « complexification » in France. In Hill, J. D., and Cumberpatch, C. G. (eds.), Different Iron Ages: Studies on the Iron Age in Temperate Europe, BAR International Series 602, Archaeopress, Oxford, pp. 121-128.

Brun, P. (2001). Échelles d'intégration politique et contrôle des moyens de production en Europe au cours du Ier millénaire av. J.-C. In Berrocal, L., and Gardes, P. (eds.), Entre celtas e iberos: las poblaciones protohistóricas de las Galias e Hispania, Real Academia de la Historia, Madrid, pp. 29-43.

Brun, P., and Chaume, B. (2013). Une éphémère tentative d'urbanisation en Europe centre-occidentale durant les Vie et Ve siècles av. J.C.? Bulletin de la Société Préhistorique Française 110: 319-349.

Brun, P., and Ruby, P. (2008). L'âge du Fer en France: premières villes, premiers états celtiques, Éditions La Découverte, Paris.

Buchsenschutz, O. (2006). Le monde rural et ses productions (IIe-Ier s. av. J.-C.). In Haselgrove, C. (ed.), Celtes et gaulois, l'archéologie face à l'histoire, 4: les mutations de la fin de l'âge du Fer, Collection Bibracte 12/4, Centre Archéologique Européen, Glux-en-Glenne, pp. 55-65.

Buchsenschutz, O. (2015). Du bourg à l'oppidum. In Buchsenschutz, O. (ed.), L'Europe celtique à l'âge du Fer (VIIIe-Ier siècle), Presses Universitaires de France, Paris, pp. 302-307.

Buchsenschutz, O., Colin, A., Firmin, G., Fischer, B., Guillaumet, J.-P., Krausz, S., Levéry, M., Marinval, P., Orellana, L., and Pierret, A. (2000). Le village celtique des Arènes à Levroux: synthèses, Supplément à la Revue Archéologique du Centre de la France, Levroux 5, Levroux.

Buchsenschutz, O., Gruel, K., and Lejars, T. (2012). L'âge d'or de l'aristocratie celtique, IVe et IIIe siècles avant J.-C. Annales, Histoire, Sciences Sociales 67: 295-324.

Buchsenschutz, O., and Ralston, I. (2012). Urbanisation et aristocratie celtiques. In Sievers, S., and Schönfelder, M. (eds.), Die Frage der Protourbanisation in der Eisenzeit/La question de la protourbanisation à l'âge du Fer, Habelt, Bonn, pp. 347-364.

Burillo-Mozota, F. (2014). The Celtiberian oppidum of Segeda. In Fernández-Götz, M., Wendling, H., and Winger, K. (eds.), Paths to Complexity: Centralisation and Urbanisation in Iron Age Europe, Oxbow Books, Oxford, pp. 214-223.

Caesar, J. (1970). De bello gallico, English trans, H. J. Edwards, Harvard University Press, Cambridge, MA.

Chapa, T. (1993). La destrucción de la escultura funeraria ibérica. Trabajos de Prehistoria 50: 185-195.

Chapman, J., and Gaydarska, B. (2016). Low-density urbanism: The case of the Trypillia group of Ukraine. In Fernández-Götz, M., and Krausse, D. (eds.), Eurasia at the Dawn of History: Urbanization and Social Change, Cambridge University Press, New York, pp. 81-105.

Chaume, B., and Mordant, C. (eds.) (2011). Le complexe aristocratique de Vix: nouvelles recherches sur l'habitat, le système de fortification et l'environnement du mont Lassois, Presses Universitaires de Dijon, Dijon.

Chaume, B., Nieszery, N., and Reinhard, W. (2013). L'enclos des grands bâtiments absidiaux du plateau du mont Saint-Marcel. Bulletin Archéologique et Historique du Châtillonnais 7ème série $\mathbf{n}^{\circ} \mathbf{4} \mathbf{7}$ ser 4: $13-19$.

Chaume, B., and Reinhard, W. (2007). Les dépôts de l'enclos cultuel hallstattien de Vix «les Herbues » et la question des enceintes quadrangulaires. Bulletin de la Société Préhistorique Française 104: 343-367.

Childe, V. G. (1950). The urban revolution. Town Planning Review 21: 3-17.

Clastres, P. (1989). Society Against the State: Essays in Political Anthropology, Zone Books, New York.

Colin, A. (1998). Chronologie des oppida de la Gaule non méditerranéenne, Éditions de la Maison des Sciences de l'Homme, Paris.

Collet, S., and Flouest, J.-L. (1997). Activités métallurgiques et commerce avec le monde méditerranéen au Ve siècle av. J.C. à Bragny-sur-Saône (Saône-et-Loire). In Brun, P., and Chaume, B. (eds.), Vix et les éphèmères principautés celtiques: les VIe et Ve siècles avant J.-C. en Europe centre-occidentale, Errance, Paris, pp. 165-172.

Collis, J. (1984). Oppida: Earliest Towns North of the Alps, Sheffield University Press, Sheffield.

Collis, J. (1995). States without centers? The Middle La Tène period in temperate Europe. In Arnold, B., and Gibson, D. B. (eds.), Celtic Chiefdom, Celtic State: The Evolution of Complex Social Systems in Prehistoric Europe, Cambridge University Press, Cambridge, pp. 75-80.

Collis, J. (2000). « Celtic » Oppida. In Hansen, M. H. (ed.), A Comparative Study of Thirty City-State Cultures, Royal Danish Academy of Sciences and Letters, Copenhagen, pp. 229-239. 
Collis, J. (2007). The polities of Gaul, Britain, and Ireland in the Late Iron Age. In Haselgrove, C., and Moore, T. (eds.), The Later Iron Age in Britain and Beyond, Oxbow Books, Oxford, pp. 523-528.

Collis, J. (2014). Urbanisation in temperate Europe in the Iron Age: Mediterranean influence or indigenous? In Fernández-Götz, M., Wendling, H., and Winger, K. (eds.), Paths to Complexity: Centralisation and Urbanisation in Iron Age Europe, Oxbow Books, Oxford, pp. 15-23.

Collis, J., Krausz, S., and Guichard, V. (2000). Les villages ouverts en Gaule centrale aux IIe et Ier siècles av. J.-C. In Guichard, V., Sievers, S., and Urban, O. H. (eds.), Les processus d'urbanisation à l'âge du Fer/Eisenzeitliche Urbanisationsprozesse, Collection Bibracte 4, Centre Archéologique Européen, Glux-en-Glenne, pp. 73-82.

Cruz, E. A. (2010). The Grand Araucanian Wars 1541-1883 in the Kingdom of Chile, Xlibris, Bloomington, IN.

Cunliffe, B. (1978). Hengistbury Head, Elek Books, London.

Cunliffe, B. (1984). Danebury: An Iron Age Hillfort in Hampshire, Volumes 1 and 2, Research Report 52, Council for British Archaeology, London.

Cunliffe, B. (1995). Danebury: An Iron Age Hillfort in Hampshire, Volume 6: A Hillfort Community in Perspective, Research Report 102, Council for British Archaeology, York.

Cunliffe, B. (2005). Iron Age Communities in Britain: An Account of England, Scotland and Wales from the Seventh Century BC until the Roman Conquest, Routledge, London.

Cunliffe, B. (2015). By Steppe, Desert, and Ocean: The Birth of Eurasia, Oxford University Press, Oxford.

Cunliffe, B., and Rowley, T. (eds.) (1976). Oppida: The Beginnings of Urbanisation in Barbarian Europe, BAR International Series 11, British Archaeological Reports, Oxford.

Danielisová, A. (2014). Oppida, production and social status: Complexity of the Late La Tène period in central Europe. In Fernández-Götz, M., Wendling, H., and Winger, K. (eds.), Paths to Complexity: Centralisation and Urbanisation in Iron Age Europe, Oxbow Books, Oxford, pp. 76-83.

Déchelette, J. (1914). Manuel d'archéologie préhistorique, celtique et gallo-romaine, II, 3, Picard, Paris.

Demoule, J.-P. (1999). La société contre les princes. In Ruby, P. (ed.), Les princes de la protohistoire et l'émergence de l'État, Centre Jean Bérad/École française de Rome, Rome, pp. 125-134.

Demoule, J.-P. (2006). Migrations et théories migratoires aux époques préhistoriques et protohistoriques. In Vitali, D. (ed.), Celtes et gaulois, l'archéologie face à l'histoire, 2: la préhistoire des celtes, Collection Bibracte 12(2), Centre Archéologique Européen, Glux-en-Glenne, pp. 17-28.

Dhennequin, L., Guillaumet, J.-P., and Szabó, M. (eds.) (2008). Bibracte (Mont Beuvray): Bilan de 10 années de recherches (1996-2005). Acta Archaeologica Hungarica 59: 1-152.

Dietler, M., and Hayden, B. (eds.) (2001). Feasts: Archaeological and Ethnographic Perspectives on Food, Politics, and Power, Smithsonian Institution Press, Washington, DC.

Drda, P., and Rybová, A. (2008). Akropole na hradišti Závist v 6.-4. stol. př. Kr. Akropolis von Závist im 6.-4. Jh. v. Chr., Památky Archeologické, Supplementum 19, Prague.

Feinman, G. M. (2013). The emergence of social complexity: Why more than population size matters. In Carballo, D. M. (ed.), Cooperation and Collective Action: Archaeological Perspectives, University Press of Colorado, Boulder, pp. 35-56.

Feinman, G. M. (2016). Variation and change in archaic states: Ritual as a mechanism of sociopolitical integration. In Murphy, J. M. (ed.), Ritual and Archaic States, University Press of Florida, Gainesville, pp. 1-22.

Fernández-Götz, M. (2013). Politik, Religion und Jahrmärkte: Zur Rolle der Volksversammlungen im eisenzeitlichen und frühmittelalterlichen Europa. In Karl, R., and Leskovar, J. (eds.), Interpretierte Eisenzeiten 5: Fallstudien, Methoden, Theorie, Studien zur Kulturgeschichte von Oberösterreich 37, Linz, pp. 71-82.

Fernández-Götz, M. (2014a). Identity and Power: The Transformation of Iron Age Societies in Northeast Gaul, Amsterdam University Press, Amsterdam.

Fernández-Götz, M. (2014b). Understanding the Heuneburg: A biographical approach. In FernándezGötz, M., Wendling, H., and Winger, K. (eds.), Paths to Complexity: Centralisation and Urbanisation in Iron Age Europe, Oxbow Books, Oxford, pp. 24-34.

Fernández-Götz, M. (2014c). Reassessing the Oppida: The role of power and religion. Oxford Journal of Archaeology 33: 379-394.

Fernández-Götz, M. (2014d). Central places and the construction of collective identities in the Middle Rhine-Moselle region. In Popa, C., and Stoddart, S. (eds.), Fingerprinting the Iron Age: Approaches to Identity in the European Iron Age, Oxbow Books, Oxford, pp. 175-186. 
Fernández-Götz, M. (in press). Contested power: Iron Age societies against the state? In Müller, J. (ed.), Archaeology of Rebellion, Habelt, Bonn.

Fernández-Götz, M., and Krausse, D. (2013). Rethinking Early Iron Age urbanisation in central Europe: The Heuneburg site and its archaeological environment. Antiquity 87: 473-487.

Fernández-Götz, M., and Krausse, D. (eds.) (2016). Eurasia at the Dawn of History: Urbanization and Social Change, Cambridge University Press, New York.

Fernández-Götz, M., and Ralston, I. (2017). Complexity and fragility of Early Iron Age urbanism in temperate Europe. Journal of World Prehistory (in press).

Fernández-Götz, M., and Roymans, N. (2015). The politics of identity: Late Iron Age sanctuaries in the Rhineland. Journal of the North Atlantic 8: 18-32.

Fernández-Götz, M., Wendling, H., and Winger, K. (eds.) (2014). Paths to Complexity: Centralisation and Urbanisation in Iron Age Europe, Oxbow Books, Oxford.

Fichtl, S. (2005a). La ville celtique: les oppida de 150 av. J.-C. à 15 ap. J.-C., Errance, Paris.

Fichtl, S. (2005b). Murus et pomerium: réflexions sur la fonction des remparts protohistoriques. Revue Archéologique du Centre de la France 44: 55-72.

Fichtl, S. (2007). Le IIIe s. av. n. è.: genèse des entités politiques en Gaule? In Mennessier-Jouannet, C., Adam, A.-M., and Milcent, P.-Y. (eds.), La gaule dans son contexte européen aux IVe et IIIe siècles avant notre ère, Édition de l'Association pour le Développement de l'Archéologie en LanguedocRoussillon, Lattes, pp. 283-289.

Fichtl, S. (ed.) (2010a). Murus celticus: architecture et fonctions des remparts de l'âge du Fer, Collection Bibracte 19, Centre Archéologique Européen, Glux-en-Glenne.

Fichtl, S. (2010b). Les places publiques dans les oppida. L'Archéologue, Archéologie Nouvelle 108: 36-40.

Fichtl, S. (2012a). Les premières villes de Gaule: le temps des oppida, Éditions Archéologie Nouvelle, Lacapelle-Marival.

Fichtl, S. (2012b). Les peuples gaulois: IIIe-Ier siècle av. J.-C., Errance, Paris.

Fichtl, S. (2012c). Du « refuge » à la ville: 150 ans d'archéologie des oppida celtiques. In Olivier, L. (ed.), Le Musée d'Archéologie Nationale et les gaulois du XIXe au XXIe siècle, Musée d'Archéologie Nationale, Saint-Germain-en-Laye, pp. 81-98.

Fichtl, S. (2012d). Places publiques et lieux de rassemblement à la fin de l'âge du Fer dans le monde celtique. In Bouet, A. (ed.), Le forum en Gaule et dans les régions voisines, Ausonius, Bordeaux, pp. 41-53.

Fichtl, S. (2013). Les agglomérations gauloises de la fin de l'âge du Fer en Europe celtique (IIIe-Ier siècles av. J.-C.). In Garcia, D. (ed.), L’habitat en Europe celtique et en Méditerranée préclassique: domaines urbains, Errance, Arles, pp. 19-43.

Fichtl, S., Le Goff, E., Mathiaut-Legros, A., and Menez, Y. (eds.) (2016). Les premières villes de l'ouest: Agglomérations gauloises de Bretagne et Pays de la Loire, Musée Archéologique de Jublains, Jublains.

Fichtl, S., Metzler, J., and Sievers, S. (2000). Le rôle des sanctuaires dans le processus d'urbanisation. In Guichard, V., Sievers, S., and Urban, O. H. (eds.), Les processus d'urbanisation à l'âge du Fer/ Eisenzeitliche Urbanisationsprozesse, Collection Bibracte 4, Centre Archéologique Européen, Gluxen-Glenne, pp. 179-186.

Fischer, T., Rieckhoff-Pauli, S., and Spindler, K. (1984). Grabungen in der spätkeltischen Siedlung im Sulztal bei Berching-Pollanten, Landkreis Neumarkt, Oberpfalz. Germania 62: 311-372.

Fleischer, F., and Rieckhoff, S. (2002). Bibract: Eine keltische Stadt, In Cain, H.-U., and Rieckhoff, S. (eds.), Fromm - Fremd - Barbarisch: Die Religion der Kelten, Verlag Philipp von Zabern, Mainz, pp. $103-118$.

Fletcher, R. (2007). The Limits of Settlement Growth: A Theoretical Outline, Cambridge University Press, Cambridge.

Fletcher, R. (2009). Low-density, agrarian-based urbanism: A comparative view. Insights 2: 2-19.

Fletcher, R. (2012). Low-density, agrarian-based urbanism: Scale, power, and ecology. In Smith, M. E. (ed.), The Comparative Archaeology of Complex Societies, Cambridge University Press, New York, pp. 285-320.

Foucault, M. (1980). Power/Knowledge: Selected Interviews and Other Writings, Pantheon, New York.

Gabrovec, S. (1974). Die Ausgrabungen in Stična und ihre Bedeutung für die südostalpine Hallstattkultur. In Symposium zu Problemen der jüngeren Hallstattzeit in Mitteleuropa, Verlag der Slowakischen Akademie der Wissenschaften, Bratislava, pp. 163-187. 
Garcia, D. (2006). Religion et société: la Gaule méridionale. In Goudineau, C. (ed.), Religion et société en Gaule, Errance, Paris, pp. 135-163.

Garcia, D. (ed.) (2013). L’habitat en Europe celtique et en Méditerranée préclassique: domaines urbains, Errance, Arles.

Gassmann, G., and Wieland, G. (2015). Early Celtic iron production at Neuenbürg in the northern Black Forest (southern Germany). In Danielisova, A., and Fernández-Götz, M. (eds.), Persistent Economic Ways of Living: Production, Distribution, and Consumption in Late Prehistory and Early History, Archaeolingua, Budapest, pp. 91-99.

Gerritsen, F., and Roymans, N. (2006). Central places and the construction of tribal identities: The case of the Late Iron Age Lower Rhine region. In Haselgrove, C. (ed.), Celtes et gaulois, l'archéologie face à l'histoire, 4: les mutations de la fin de l'âge du Fer, Collection Bibracte 12/4, Centre Archéologique Européen, Glux-en-Glenne, pp. 251-266.

González-Ruibal, A. (2012). The politics of identity: Ethnicity and the economy of power in Iron Age northern Iberia. In Cifani, G., and Stoddart, S. (eds.), Landscape, Ethnicity and Identity in the Archaic Mediterranean Area, Oxbow Books, Oxford, pp. 245-266.

Gruel, K., and Buchsenschutz, O. (2015). Un urbanisme perché. In O. Buchsenschutz (ed.), L'Europe celtique à l'âge du Fer (VIIIe-Ier siècle), Presses Universitaires de France, Paris, pp. 307-315.

Guichard, V., and Paris, P. (2013). Chroniques des recherches sur le Mont Beuvray 2009-2012. Revue Archéologique de l'Est 62: 113-155.

Guichard, V., Sievers, S., and Urban, O. H. (eds.) (2000). Les processus d'urbanisation à l'âge du Fer/ Eisenzeitliche Urbanisationsprozesse, Collection Bibracte 4, Centre Archéologique Européen, Gluxen-Glenne.

Hamilton, D., Haselgrove, C., and Gosden, C. (2015). The impact of Bayesian chronologies on the British Iron Age. World Archaeology 47: 642-660.

Hansen, L., Krausse, D., Tarpini, R., and Wahl, J. (2015). Besiedlungs- und Kulturlandschaftsentwicklung im Umfeld der Heuneburg während der Hallstatt- und Frühlatènezeit - erste Ergebnisse. Archäologisches Korrespondenzblatt 45: 499-518.

Harding, D. (2012). Iron Age Hillforts in Britain and Beyond, Oxford University Press, Oxford.

Haselgrove, C. (2000). The character of oppida in Iron Age Britain. In Guichard, V., Sievers, S., and Urban, O. H. (eds.), Les processus d'urbanisation à l'âge du Fer/Eisenzeitliche Urbanisationsprozesse, Collection Bibracte 4, Centre Archéologique Européen, Glux-en-Glenne, pp. 103-110.

Haselgrove, C. (ed.) (2016). Cartimandua's Capital? The Late Iron Age Royal Site at Stanwick, North Yorkshire, Fieldwork and Analysis 1981-2011, Oxbow Books, Oxford.

Haselgrove, C., and Guichard, V. (2013). Les gaulois sont-ils dans la plaine? Reflections on settlement patterns in Gaul in the 1st century BC. In Krausz, S., Colin, A., Gruel, K., Ralston, I., and Dechezleprêtre, T. (eds.), L'âge du Fer en Europe: mélanges offerts à Olivier Buchsenschutz, Ausonius, Paris, pp. 317-328.

Haselgrove, C., Hamilton, D., and Gosden, C. (in press). Iron Age Settlement and Society in Central Southern Britain: A New Chronological Perspective, OUSA Monographs, Oxford.

Hayden, B. (2014). The Power of Feasts: From Prehistory to the Present, Cambridge University Press, New York.

Herrmann, F.-R. (2005). Glauberg: Olympia des Nordens oder unvollendete Stadtgründung? In Biel, J., and Krausse, D. (eds.), Frühkeltische Fürstensitze: Älteste Städte und Herrschaftszentren nördlich der Alpen? Archäologische Informationen aus Baden-Württemberg 51, Esslingen, pp. 18-27.

Hill, J. D. (2006). Are we any closer to understanding how later Iron Age societies worked (or did not work)? In Haselgrove, C. (ed.), Celtes et gaulois, l'archéologie face à l'histoire, 4: les mutations de la fin de l'âge du Fer, Collection Bibracte 12(4), Centre Archéologique Européen, Glux-en-Glenne, pp. 169-179.

Holzer, V. (2014). Roseldorf: An enclosed central settlement of the Early and Middle La Tène period in Lower Austria (Roseldorf/Němčice Centre). In Fernández-Götz, M., Wendling, H., and Winger, K. (eds.), Paths to Complexity: Centralisation and Urbanisation in Iron Age Europe, Oxbow Books, Oxford, pp. 122-131.

Jerem, E. (2012). Sopron-Várhely (Burgstall), Ungarn. In Sievers, S., Urban, O. H., and Ramsl, P. (eds.), Lexikon zur Keltischen Archäologie, Verlag der Österreichischen Akademie der Wissenschaften, Vienna, pp. 1748-1750.

Johnson, A. W., and Earle, T. (2000). The Evolution of Human Societies: From Foraging Group to Agrarian State, Stanford University Press, Stanford. 
Kaenel, G. (2006). Agglomérations et oppida de la fin de l'âge du Fer: une vision synthétique. In Haselgrove, C. (ed.), Celtes et gaulois, l'archéologie face à l'histoire, 4: les mutations de la fin de l'âge du Fer, Collection Bibracte 12(4), Centre Archéologique Européen, Glux-en-Glenne, pp. 17-39.

Kimmig, W. (1983). Die griechische Kolonisation im westlichen Mittelmeergebiet und ihre Wirkung auf die Landschaften des westlichen Mitteleuropa. Jahrbuch Römisch-Germanisches Zentralmuseum 30: $5-78$.

Krausse, D. (2006a). Eisenzeitlicher Kulturwandel und Romanisierung im Mosel-Eifel-Raum, RömischGermanische Forschungen 63, Mainz.

Krausse, D. (2006b). Prunkgräber der nordwestalpinen Späthallstattkultur: Neue Fragestellungen und Untersuchungen zu ihrer sozialhistorischen Deutung. In Carnap-Bornheim, C. von, Krausse, D., and Wesse, A. (eds.), Herrschaft - Tod - Bestattung: Zu den vor- und frühgeschichtlichen Prunkgräbern als archäologisch-historische Quelle, Habelt, Bonn, pp. 61-80.

Krausse, D. (ed.) (2008a). Frühe Zentralisierungs- und Urbanisierungsprozesse: Zur Genese und Entwicklung frühkeltischer Fürstensitze und ihres territorialen Umlandes, Forschungen und Berichte zur Vor- und Frühgeschichte in Baden-Württemberg 101, Stuttgart.

Krausse, D. (2008b). Etappen der Zentralisierung nördlich der Alpen: Hypothesen, Modelle, Folgerungen. In Krausse, D. (ed.), Frühe Zentralisierungs- und Urbanisierungsprozesse: Zur Genese und Entwicklung frühkeltischer Fürstensitze und ihres territorialen Umlandes, Forschungen und Berichte zur Vor- und Frühgeschichte in Baden-Württemberg 101, Stuttgart, pp. 435-450.

Krausse, D. (ed.) (2010). "Fürstensitze" und Zentralorte der frühen Kelten, Teil I und II, Forschungen und Berichte zur Vor- und Frühgeschichte in Baden-Württemberg 120, Stuttgart.

Krausse, D., Fernández-Götz, M., Hansen, L., and Kretschmer, I. (2016): The Heuneburg and the Early Iron Age Princely Seats: First Towns North of the Alps, Archaeolingua, Budapest.

Krausse, D., and Nakoinz, O. (2000). Binnenkolonisation und Zentralisation: Überlegungen zur latènezeitlichen Besiedlungs- und Bevölkerungsentwicklung im Mittelgebirgsraum nordwestlich der Mosel. In Guichard, V., Sievers, S., and Urban, O. H. (eds.), Les processus d'urbanisation à l'âge $d u$ Fer/Eisenzeitliche Urbanisationsprozesse, Collection Bibracte 4, Centre Archéologique Européen, Glux-en-Glenne, pp. 127-140.

Kristiansen, K. (1998). Europe Before History, Cambridge University Press, Cambridge.

Kurz, S. (2010). Zur Genese und Entwicklung der Heuneburg in der späten Hallstattzeit. In Krausse, D. (ed.), "Fürstensitze" und Zentralorte der frühen Kelten, Teil I: Forschungen und Berichte zur Vorund Frühgeschichte in Baden-Württemberg 120(1), Stuttgart, pp. 239-256.

Kysela, J. (2009). Beaten Boii and unattested urbanization: Observations on the theory of a north Italian origin of the oppida. In Karl, R., and Leskovar, J. (eds.), Interpretierte Eisenzeiten 3: Fallstudien, Methoden, Theorie, Studien zur Kulturgeschichte von Oberösterreich 18, Linz, pp. 227-235.

Lambot, B. (2006). Religion et habitat: les fouilles d'Acy-Romance. In Goudineau, C. (ed.), Religion et société en Gaule, Errance, Paris, pp. 176-189.

Lawrence, D., Philip, G., Hunt, H., Snape-Kennedy, L, and Wilkinson, T. J. (2016). Long term population, city size and climate trends in the Fertile Crescent: A first approximation. PLOS ONE 11: $1-16$.

Leighton, R. (2013). Urbanization in southern Etruria from the 10th to the 6th century BC: The origins and growth of major centres. In Turfa, J. M. (ed.), The Etruscan World, Routledge, London, pp. 134-150.

Liverani, M. (2013). Immaginare Babele: due secoli di studi sulla città orientale antica, Laterza, Rome.

Livy (1924). Ab Urbe Condita, English trans. B. O. Foster, Harvard University Press, Cambridge Mass.

Lukas, D. (2014). A historical-semantic approach to the concept of 'oppidum': The example of Bibracte. In Fernández-Götz, M., Wendling, H., and Winger, K. (eds.), Paths to Complexity: Centralisation and Urbanisation in Iron Age Europe, Oxbow Books, Oxford, pp. 84-100.

Maise, C. (1998). Archäoklimatologie: Vom Einfluss nacheiszeitlicher Klimavariabilität in der Ur- und Frühgeschichte. Jahrbuch der Schweizerischen Gesellschaft für Ur- und Frühgeschichte 81: 197-235.

Malrain, F., Matterne, V., and Méniel, P. (2002). Les paysans gaulois, Errance, Paris.

Marcus, J., and Sabloff, J. (ed.) (2008). The Ancient City: New Perspectives on Urbanism in the Old and New World, School for Advanced Research Press, Santa Fe, NM.

Metzler, J. (1995). Das treverische Oppidum auf dem Titelberg (G.-H. Luxemburg): Zur Kontinuität zwischen der spätkeltischen und der frührömischen Zeit in Nord-Gallien, Dossiers d'Archéologie du Musée National d'Histoire et d'Art 3, Luxembourg. 
Metzler, J., Méniel, P., and Gaeng, C. (2006). Oppida et espaces publics. In C. Haselgrove (ed.), Celtes et gaulois, l'archéologie face à l'histoire, 4: les mutations de la fin de l'âge du Fer, Collection Bibracte 12(4), Centre Archéologique Européen, Glux-en-Glenne, pp. 201-224.

Metzler, J., Gaeng, C., and Méniel, P. (2016). L'espace public du Titelberg, Dossiers d'Archéologie du Musée National d'Histoire et d'Art 17, Luxembourg.

Meylan, F., Perrin, F., and Schönfelder, M. (2002). L'artisanat dans les oppida d'Europe tempérée: un état de la question. In Béal, J.-C., and Goyon, J.-C. (eds.), Les artisans dans la ville antique, Université Lumière-Lyon 2, Lyon, pp. 77-99.

Milcent, P.-Y. (ed.) (2007). Bourges-Avaricum: un centre proto-urbain celtique du Ve s. av. J.-C., Bituriga, Bourges.

Milcent, P.-Y. (2014). Hallstatt urban experience before the Celtic Oppida in central and eastern Gaul: Two cases-studies: Bourges and Vix. In Fernández-Götz, M., Wendling, H., and Winger, K. (eds.), Paths to Complexity: Centralisation and Urbanisation in Iron Age Europe, Oxbow Books, Oxford, 35-51.

Modarressi-Tehrani, D. (2009). Untersuchungen zum früheisenzeitlichen Metallhandwerk im westlichen Hallstatt- und Frühlatènegebiet, Verlag Marie Leidorf, Rahden.

Möllers, S. (2009). Die Schnippenburg bei Ostercappeln, Landkreis Osnabrück, in ihren regionalen und chronologischen Bezügen, Verlag Marie Leidorf, Rahden.

Moore, J. D. (1996). The archaeology of plazas and the proxemics of ritual: Three Andean traditions. American Anthropologist 98: 789-802.

Moore, T. (2012). Beyond the oppida: Polyfocal complexes and Late Iron Age societies in southern Britain. Oxford Journal of Archaeology 31: 391-417.

Moore, T. (2014). The birth of a capital? Bagendon 'oppidum' and the impact of Rome on the British countryside. In Breeze, D. (ed.), The Impact of Rome on the British Countryside, Royal Archaeological Institute, London, pp. 26-30.

Moore, T. (2017). Beyond Iron Age 'towns': Examining oppida as examples of low-density urbanism. Oxford Journal of Archaeology 36: 287-305.

Moore, T., Braun, A., Creighton, J., Cripps, L., Haupt, P., Klenner, I., Nouvel, P., Ponroy, C., and Schönfelder, M. (2013). Oppida, agglomerations and suburbia: The Bibracte environs and new perspectives on Late Iron Age urbanism in central-eastern France. European Journal of Archaeology 16: 491-517.

Moore, T., and Ponroy, C. (2014). What's in a wall? Considerations on the role of open settlements in Late La Tène Gaul. In Fernández-Götz, M., Wendling, H., and Winger, K. (eds.), Paths to Complexity: Centralisation and Urbanisation in Iron Age Europe, Oxbow Books, Oxford, pp. $140-155$.

Moret, P. (2017). The purpose of Gallic oppida ramparts: A reappraisal. In Ballmer, A., Fernández-Götz, M., and Mielke, D. P. (eds.), Understanding Ancient Fortifications: Between Regionality and Connectivity, Oxbow Books, Oxford (in press).

Müller, J. (2016). From the Neolithic to the Iron Age: Demography and social agglomeration: The development of centralized control? In Fernández-Götz, M., and Krausse, D. (eds.), Eurasia at the Dawn of History: Urbanization and Social Change, Cambridge University Press, New York, pp. 106-124.

Müller, J., Rassmann, K., and Videiko, M. (eds.) (2016). Trypillia: Mega-Sites and European Prehistory 4100-3400 BCE, Routledge, New York.

Nicolai, C. von (2014). Symbolic meanings of Iron Age hillfort defences in continental Europe. In Fernández-Götz, M., Wendling, H., and Winger, K. (eds.), Paths to Complexity: Centralisation and Urbanisation in Iron Age Europe, Oxbow Books, Oxford, pp. 111-121.

Nortmann, H. (1990). Die Altburg bei Bundenbach: Ein Führer zur keltischen Burg, Herausgegeben von der Gemeinde Bundenbach, Bundenbach.

Ortman, S. G., Cabaniss, A. H., Sturm, J. O., and Bettencourt, L. M. (2014). The pre-history of urban scaling. PLOS ONE 9: 1-10.

Osborne, R., and Cunliffe, C. (eds.) (2005). Mediterranean Urbanization 800-600 BC, Oxford University Press, Oxford.

Pauli, L. (1985). Early Celtic society: Two centuries of wealth and turmoil in central Europe. In Champion, T. C., and Megaw, J. V. (eds.), Settlement and Society: Aspects of West European Prehistory in the First Millennium BC, Leicester University Press, Leicester, pp. 23-43.

Pierrevelcin, G. (2012). Les plus grands sites gaulois: atlas des oppida, Editions Archéologie Nouvelle, Lacapelle-Marival. 
Piotrowski, W. (1995). Biskupin: The fortified settlement from the first millennium BC. Quaternary Studies in Poland 13: 89-99.

Pitts, M. (2010). Re-thinking the southern British Oppida: Networks, kingdoms and material culture. European Journal of Archaeology 13: 32-63.

Poux, M. (2004). L'âge du vin: rites de boisson, festins et libations en Gaule indépendante, Éditions Monique Mergoil, Montagnac.

Poux, M. (ed.) (2012). Corent: voyage au coeur d'une ville gauloise, Errance, Paris.

Poux, M. (2014). Enlarging oppida: Multipolar town patterns in Late Iron Age Gaul. In Fernández-Götz, M., Wendling, H., and Winger, K. (eds.), Paths to Complexity: Centralisation and Urbanisation in Iron Age Europe, Oxbow Books, Oxford, pp. 156-166.

Poux, M., and Demierre, M. (eds.) (2016). Le sanctuaire de Corent (Puy-de-Dôme, Auvergne): Vestiges et rituels, Supplément à Gallia, Nanterre.

Ralston, I. (2010). Fragile states in mid-first millennium BC temperate western Europe? The view from Bourges. Social Evolution \& History 9: 135-159.

Ralston, I. (2013). Celtic Fortifications, History Press, Stroud.

Ramona, J. (2011). Agglomérations gauloises: nouvelles considerations. Les Dossiers d'Archéologie H.S. 21: $46-51$.

Renfrew, C. (2016). Cognitive archaeology and the making of the human mind. In Fernández-Götz, M., and Krausse, D. (eds.), Eurasia at the Dawn of History: Urbanization and Social Change, Cambridge University Press, New York, pp. 23-39.

Renfrew, C., and Cherry, J. F. (eds.) (1986). Peer Polity Interaction and Socio-political Change, Cambridge University Press, Cambridge.

Rieckhoff, S. (1995). Süddeutschland im Spannungsfeld von Kelten, Germanen und Römern, Trierer Zeitschrift Beiheft 19, Trier.

Rieckhoff, S. (2014). Space, architecture and identity in Gaul in the 2nd/1st centuries BC. In FernándezGötz, M., Wendling, H., and Winger, K. (eds.), Paths to Complexity: Centralisation and Urbanisation in Iron Age Europe, Oxbow Books, Oxford, pp. 101-110.

Rieckhoff, S., and Fichtl, S. (2011). Keltenstädte aus der Luft, Konrad Theiss Verlag, Stuttgart.

Rieckhoff, S., Hoppadietz, R., and Mölders, D. (2009). Urbanisierung und Romanisierung im Spiegel der Architektur im keltischen Oppidum Bibracte-Mont Beuvray (Burgund, Frankreich). In Trebsche, P., Balzer, I., Eggl, C., Fries-Knoblach, J., Koch, J. K., and Wiethold, J. (eds.), Architektur: Interpretation und Rekonstruktion, Beier und Beran, Langenweißenbach, pp. 141-149.

Riva, C. (2010). The Urbanisation of Etruria, Cambridge University Press, Cambridge.

Ruiz-Zapatero, G. (2005). Guía del castro de Ulaca, Institución Gran Duque de Alba, Ávila.

Ruiz-Zapatero, G. (2011). El caleidoscopio urbano en el mundo 'céltico' de la Meseta. In ÁlvarezSanchís, J. R., Jimeno, A., and Ruiz-Zapatero, G. (eds.), Aldeas y ciudades en el primer milenio a.C. La Meseta Norte y los orígenes del urbanismo, Complutum 22 (2), Universidad Complutense, Madrid, pp. 297-309.

Ruiz-Zapatero, G., and Álvarez-Sanchís, J. R. (1995). Las Cogotas: Oppida and the roots of urbanism in the Spanish Meseta. In Cunliffe, B., and Keay, S. (eds.), Social Complexity and the Development of Towns in Iberia: From the Copper Age to the Second Century AD, British Academy, London, pp. 209-236.

Salač, V. (2009). Zur Interpretation der Oppida in Böhmen und in Mitteleuropa. In Karl, R., and Leskovar, J. (eds.), Interpretierte Eisenzeiten 3: Fallstudien, Methoden, Theorie, Studien zur Kulturgeschichte von Oberösterreich 18, Linz, pp. 237-252.

Salač, V. (2012). Les oppida et les processus d'urbanisation en Europe central. In Sievers, S., and Schönfelder, M. (eds.), Die Frage der Protourbanisation in der Eisenzeit/La question de la protourbanisation à l'âge du Fer, Habelt, Bonn, pp. 319-345.

Salač, V. (2014). Oppida and urbanisation processes in central Europe. In Fernández-Götz, M., Wendling, H., and Winger, K. (eds.), Paths to Complexity: Centralisation and Urbanisation in Iron Age Europe, Oxbow Books, Oxford, pp. 64-75.

Salač, V., and Buchsenschutz, O. (2014). Aux origines des villes celtes. Pour la Science 437: 38-45.

Salač, V., and Bemmann, J. (eds.) (2009). Mitteleuropa zur Zeit Marbods, Archeologický ústav Akademie věd České republiky, Prague.

Sanmark, A., Iversen, F., Mehler, N., and Semple, S. (eds.) (2015-2016). Debating the Thing in the North II: Selected Papers from Workshops Organized by The Assembly Project, Journal of the North Atlantic 8 (special issue). 
Schäfer, A. (2010). Berching-Pollanten II: Die Kleinfunde der jüngerlatènezeitlichen Siedlung BerchingPollanten, Lkr. Neumarkt i.d. Oberpfalz, Verlag Marie Leidorf, Rahden.

Schatz, K., and Stephan, E. (2008). Archäozoologie frühkeltischer Faunenfunde. In Krausse, D. (ed.), Frühe Zentralisierungs- und Urbanisierungsprozesse: Zur Genese und Entwicklung frühkeltischer Fürstensitze und ihres territorialen Umlandes, Forschungen und Berichte zur Vor- und Frühgeschichte in Baden-Württemberg 101, Stuttgart, pp. 349-366.

Scott, J. C. (2009). The Art of Not Being Governed: An Anarchist History of Upland Southeast Asia, Yale University Press, New Haven, CT.

Schulze-Forster, J. (2007). Die Burgen der Mittelgebirgszone: Eisenzeitliche Fluchtburgen, befestigte Siedlungen, Zentralorte oder Kultplätze? In Möllers, S., and Zehm, B. (eds.), Rätsel Schnippenburg: Sagenhafte Funde aus der Keltenzeit, Habelt, Bonn, pp. 109-143.

Sharples, N. (2014). Are the developed hillforts of southern England urban? In Fernández-Götz, M., Wendling, H., and Winger, K. (eds.), Paths to Complexity: Centralisation and Urbanisation in Iron Age Europe, Oxbow Books, Oxford, pp. 224-232.

Sievers, S. (2006). Oppida und ihre linearen Strukturen. In Harding, A., Sievers, S., and Venclová, N. (eds.), Enclosing the Past: Inside and Outside in Prehistory, J. R. Collis Publications, Sheffield, pp. 126-134.

Sievers, S. (2007). Manching: Die Keltenstadt, Konrad Theiss Verlag, Stuttgart.

Sievers, S. (2012). Manching: Ein Oppidum nach Plan? In Raeck, W., and Steuernagel, D. (eds.), Das Gebaute und das Gedachte: Siedlungsform, Architektur und Gesellschaft in prähistorischen und antiken Kulturen, Habelt, Bonn, pp. 115-123.

Sievers, S., and Schönfelder, M. (eds.) (2012). Die Frage der Protourbanisation in der Eisenzeit/La question de la proto-urbanisation à l'âge du Fer, Habelt, Bonn.

Sindbæk, S. M. (2007). Networks and nodal points: The emergence of towns in early Viking Age Scandinavia. Antiquity 81: 119-132.

Sirocko, F. (ed.) (2009). Wetter, Klima, Menschheitsentwicklung: Von der Eiszeit bis ins 21. Jahrhundert, Konrad Theiss Verlag, Stuttgart.

Smith, M. E. (2010). The archaeological study of neighborhoods and districts in ancient cities. Journal of Anthropological Archaeology 29: 137-154.

Smith, M. E. (ed.) (2012). The Comparative Archaeology of Complex Societies, Cambridge University Press, New York.

Smith, M. E. (2014). Foreword. In Fernández-Götz, M., Wendling, H., and Winger, K. (eds.), Paths to Complexity: Centralisation and Urbanisation in Iron Age Europe, Oxbow Books, Oxford, pp. v-vi.

Smith, M. E. (2016). How can archaeologists identify early cities? Definitions, types, and attributes. In Fernández-Götz, M., and Krausse, D. (eds.), Eurasia at the Dawn of History: Urbanization and Social Change, Cambridge University Press, New York, pp. 153-168.

Smith, M. G. (1972). Complexity, size and urbanization. In Ucko, P., Tringham, R., and Dimbleby, G. W. (eds.), Man, Settlement and Urbanism, Duckworth, London, pp. 567-574.

Smith, M. L. (ed.) (2003). The Social Construction of Ancient Cities, Smithsonian Institution Press, Washington, DC.

Smith, M. L. (2008). Urban empty spaces: Contentious places for consensus-building. Archaeological Dialogues 15: 216-231.

Stanley, B. W., Stark, B. L., Johnston, K., and Smith, M. E. (2012). Urban open spaces in historical perspective: A transdisciplinary typology and analysis. Urban Geography 33: 1089-1117.

Storey, G. R. (ed.) (2006). Urbanism in the Preindustrial World: Cross-Cultural Approaches, University of Alabama Press, Tuscaloosa.

Szabó, M., Timar, L., and Szabó, D. (2007). La basilique de Bibracte: un témoignage précoce de l'architecture romaine en Gaule centrale. Archäologisches Korrespondenzblatt 37: 389-408.

Testart, A. (2005). Eléments de classification des sociétés, Errance, Paris.

Tomaschitz, K. (2002). Die Wanderungen der Kelten in der antiken literarischen Überlieferung, Mitteilungen der Prähistorischen Kommission 47, Vienna.

Torres-Martínez, J. F., Fernández-Götz, M., Martínez-Velasco, A., Vacas, D., and Rodríguez-Millán, E. (2016). From the Bronze Age to the Roman conquest: The oppidum of Monte Bernorio (northern Spain). Proceedings of the Prehistoric Society 82: 363-382.

Tsukamoto, K., and Inomata, T. (eds.) (2014). Mesoamerican Plazas: Arenas of Community and Power, University of Arizona Press, Tucson. 
Van der Vaart-Verschoof, S., and Schumann, R. (eds.) (2017). Connected Elites and Regions in the Early Hallstatt Period ( $\mathrm{Ha}$ C): Perspectives from the Low Lands to the Circumalpine Region, Sidestone Press, Leiden.

Verger, S. (2009). Société, politique et religion en Gaule avant la conquête: éléments pour une étude anthropologique. Pallas 80: 61-82.

Verger, S. (2015). L'âge du Fer ancien: l'Europe moyenne avant les celtes historiques (800-400). In Buchsenschutz, O. (ed.), L'Europe celtique à l'âge du Fer (VIIIe-Ier siècle), Presses Universitaires de France, Paris, pp. 75-176.

Wells, P. S. (1984). Farms, Villages and Cities: Commerce and Urban Origins in Late Prehistoric Europe, Cornell University Press, Ithaca, NY.

Wells, P. S. (1996). Location, organization, and specialization of craft production in late prehistoric central Europe. In Wailes, B. (ed.), Craft Specialization and Social Evolution: In Memory of V. Gordon Childe, University Museum of Archaeology and Anthropology, University of Pennsylvania, Philadelphia, pp. 85-98.

Wells, P. S. (2006). Objects, meanings and ritual in the emergence of the oppida. In Haselgrove, C. (ed.), Celtes et gaulois, l'archéologie face à l'histoire, 4: les mutations de la fin de l'âge du Fer, Collection Bibracte 12(4), Centre Archéologique Européen, Glux-en-Glenne, pp. 139-153.

Wendling, H. (2013). Manching reconsidered: New perspectives on settlement dynamics and urbanization in Iron Age central Europe. European Journal of Archaeology 16: 459-490.

Wendling, H., and Winger, K. (2014). Aspects of Iron Age urbanity and urbanism at Manching. In Fernández-Götz, M., Wendling, H., and Winger, K. (eds.), Paths to Complexity: Centralisation and Urbanisation in Iron Age Europe, Oxbow Books, Oxford, pp. 132-139.

Wigg, D. (1996). Das Ende der keltischen Münzgeldwirtschaft am Mittelrhein. Germania 74: 377-397.

Woolley, H. (2003). Urban Open Spaces, Spon Press, London.

Woolf, G. (1993). Rethinking the oppida. Oxford Journal of Archaeology 12: 223-234.

Woolf, G. (2006). The end of «the end of the Iron Age »? In Haselgrove, C. (ed.), Celtes et gaulois, l'archéologie face à l'histoire, 4: les mutations de la fin de l'âge du Fer, Collection Bibracte 12(4), Centre Archéologique Européen, Glux-en-Glenne, pp. 267-276.

Yoffee, N. (ed.) (2015). The Cambridge World History, Volume 3: Early Cities in Comparative Perspective, 4000 BCE-1200 CE, Cambridge University Press, Cambridge.

\section{Bibliography of Recent Literature}

Ade, D., Fernández-Götz, M., Rademacher, L., Stegmaier, G., and Willmy, A. (2012). Der Heidengraben: Ein keltisches Oppidum auf der Schwäbischen Alb, Konrad Theiss Verlag, Stuttgart.

Almagro-Gorbea, M., and Lorrio, A. (2011). Teutates: El Héroe Fundador y el culto heroico al antepasado en Hispania y en la Keltiké, Real Academia de la Historia, Madrid.

Arnold, B. (2010). Eventful archaeology, the Heuneburg mudbrick wall, and the Early Iron Age of southwest Germany. In Bolender, D. (ed.), Eventful Archaeologies: New Approaches to Social Transformation in the Archaeological Record, State University of New York Press, Albany, pp. $100-114$.

Arnold, B., and Gibson, D. B. (eds.) (1995). Celtic Chiefdom, Celtic State: The Evolution of Complex Social Systems in Prehistoric Europe, Cambridge University Press, Cambridge.

Balzer, I. (2009). Chronologisch-chorologische Untersuchung des späthallstatt- und frühlatènezeitlichen "Fürstensitzes" auf dem Münsterberg von Breisach (Grabungen 1980-1986), Materialhefte zur Archäologie in Baden-Württemberg 84, Stuttgart.

Balzer, I. (2010). Neue Forschungen zu alten Fragen. Der früheisenzeitliche "Fürstensitz" Hohenasperg (Kr. Ludwigsburg) und sein Umland. In Krausse, D. (ed.), "Fürstensitze" und Zentralorte der frühen Kelten: Teil I, Forschungen und Berichte zur Vor- und Frühgeschichte in BadenWürttemberg 120(1), Stuttgart, pp. 209-238.

Bessiere, F., and Guichard, V. (2010). Chronique des recherches sur le Mont Beuvray 2006-2008. Revue Archéologique de l'Est 59: 211-239.

Biel, J., and Krausse, D. (eds.) (2005). Frühkeltische Fürstensitze: Älteste Städte und Herrschaftszentren nördlich der Alpen? Archäologische Informationen aus Baden-Württemberg 51, Esslingen.

Bonomi, S., and Guggisberg, M. A. (eds.) (2015). Griechische Keramik nördlich von Etrurien: Mediterrane Importe und archäologischer Kontext, Reichert Verlag, Wiesbaden. 
Brun, P., and Chaume, B. (eds.) (1997). Vix et les éphèmères principautés celtiques: les VIe et Ve siècles avant J.-C. en Europe centre-occidentale, Errance, Paris.

Brun, P., Chartier, M., and Pion, P. (2000). Le processus d'urbanisation dans la vallée de l'Aisne. In Guichard, V., Sievers, S., and Urban, O. H. (eds.), Les processus d'urbanisation à l'âge du Fer/ Eisenzeitliche Urbanisationsprozesse, Collection Bibracte 4, Centre Archéologique Européen, Gluxen-Glenne, pp. 83-96.

Chaume, B. (2001). Vix et son territoire à l'âge du Fer: fouilles du Mont Lassois et environnement du site princier, Collection Protohistoire Européenne 6, Montagnac.

Chytráček, M., Danielisová, A., Trefný, M., and Slabina, M. (2010). Zentralisierungsprozesse und Siedlungsdynamik in Böhmen (8.-4. Jh. v. Chr.). In Krausse, D. (ed.), "Fürstensitze" und Zentralorte der frühen Kelten: Teil II, Forschungen und Berichte zur Vor- und Frühgeschichte in Baden-Württemberg 120(2), Stuttgart, pp. 155-173.

Collis, J. (1996). Urbanisation in Atlantic Europe in the Iron Age. Gallaecia 14/15: 223-241.

Collis, J. (2006). The Celts: Origins, Myths and Inventions, Tempus, Stroud.

Cunliffe, B. (1990). Before hillforts. Oxford Journal of Archaeology 9: 323-336.

Cunliffe, B. (1994). After hillforts. Oxford Journal of Archaeology 13: 71-84.

Danielisová, A. (2010). Oppidum České Lhotice v kontextu svého sídelního zázemí (Oppidum České Lhotice and Its Hinterland), Archeologické Studijní Materiály 17, Prague.

Deberge, Y., Vermulen, C., and Collis, J. (2007). Le complexe de Gandaillat/La Grande Borne: un état de la question. In Menessier-Jouannet, C., and Deberge, Y. (eds.), L'archéologie de l'âge du Fer en Auvergne, Édition de l'Association pour le Développement de l'Archéologie en LanguedocRoussillon, Lattes, pp. 267-289.

Eller, M., Sievers, S., Wendling, H., and Winger, K. (2012). Zentralisierung und Urbanisierung: Manchings Entwicklung zur spätkeltischen Stadt. In Sievers, S., and Schönfelder, M. (eds.), Die Frage der Protourbanisation in der Eisenzeit/La question de la proto-urbanisation à l'âge du Fer, Habelt, Bonn, pp. 303-318.

Fernández-Götz, M. (2012). Die Rolle der Heiligtümer bei der Konstruktion kollektiver Identitäten: Das Beispiel der treverischen Oppida. Archäologisches Korrespondenzblatt 42: 509-524.

Fernández-Götz, M. (2013). Una nueva mirada sobre los oppida de la Europa templada. Complutum 24: $131-150$.

Fernández-Götz, M. (2014e). Villages and cities in Early Europe. Antiquity 88: 304-307.

Fernández-Götz, M. (2014f). Sanctuaries and ancestor worship at the origin of the oppida. In Sirbu, V., and Matei, S. (eds.), Residential Centres (Dava, Emporium, Oppidum, Hillfort, Polis) and Cult Places in the Second Iron Age of Europe, Mousaios 19, Muzeul Judetean Buzău, Buzău, pp. 111-132.

Fernández-Götz, M., and Krausse, D. (2012). Heuneburg: First city north of the Alps. Current World Archaeology 55: 28-34.

Fichtl, S. (ed.) (2003). Les oppida du nord-est de la Gaule à La Tène finale, Archaeologia Mosellana 5, Strasbourg.

Fichtl, S. (ed.) (2005). Hiérarchie de l'habitat rural dans le nord-est de la Gaule à La Tène Moyenne et Finale, Archaeologia Mosellana 6, Strasbourg.

Fischer, E., Rösch, M., Sillmann, M., Ehrmann, O., Liese-Kleiber, H., Voigt, R., Stobbe, A., Kalis, A. E. J., Stephan, E., Schatz, K., and Posluschny, A. (2010). Landnutzung im Umkreis der Zentralorte Hohenasperg, Heuneburg und Ipf: Archäobotanische und archäozoologische Untersuchungen und Modellberechnungen zum Ertragspotential von Ackerbau und Viehhaltung. In Krausse, D. (ed.), "Fürstensitze" und Zentralorte der frühen Kelten, Teil II, Forschungen und Berichte zur Vor- und Frühgeschichte in Baden-Württemberg 120(2), Stuttgart, pp. 195-265.

Frankenstein, S., and Rowlands, M. J. (1978). The internal structure and regional context of Early Iron Age society in south-western Germany. Bulletin of the Institute of Archaeology 15: 73-112.

Garcia, D., and Verdin, F. (eds.) (2002). Territoires celtiques: espaces ethniques et territoires des agglomérations protohistoriques d'Europe occidentale, Errance, Paris.

Gersbach, E. (1989). Ausgrabungsmethodik und Stratigraphie der Heuneburg, Heuneburgstudien 6, Römisch-Germanische Forschungen 45, Mainz.

Gersbach, E. (1995). Baubefunde der Perioden IVc-IVa der Heuneburg, Heuneburgstudien 9, RömischGermanische Forschungen 53, Mainz.

Gersbach, E. (1996). Baubefunde der Perioden IIIb-Ia der Heuneburg, Heuneburgstudien 10, RömischGermanische Forschungen 56, Mainz. 
Goudineau, C., Guichard, V., and Kaenel, G. (eds.) (2010). Celtes et gaulois, l'archéologie face à l'histoire: colloque de synthèse, Collection Bibracte 12(6), Centre Archéologique Européen, Gluxen-Glenne.

Haselgrove, C. (ed.) (2006). Celtes et gaulois, l'archéologie face à l'histoire, 4: les mutations de la fin de l'âge du Fer, Collection Bibracte 12(4), Centre Archéologique Européen, Glux-en-Glenne.

Haselgrove, C., and Moore, T. (eds.) (2007). The Later Iron Age in Britain and Beyond, Oxbow Books, Oxford.

Haselgrove, C., and Pope, R. (eds.) (2007). The Earlier Iron Age in Britain and the Near Continent, Oxbow Books, Oxford.

Kaenel, G., Curdy, P., and Carrard, F. (2004). L'oppidum du Mont Vully: un bilan des recherches 19782003, Archéologie Fribourgeoise 20, Fribourg.

Kimmig, W. (1969). Zum Problem späthallstättischer Adelssitze. In Otto, K.-H., and Herrmann, J. (eds.), Siedlung, Burg und Stadt. Studien zu ihren Anfängen: Festschrift für Paul Grimm, Deutsche Akademie der Wissenschaften, Berlin, pp. 95-113.

Krause, R. (ed.) (2014). Neue Forschungen zum frühkeltischen Fürstensitz auf dem Ipf, Frankfurter Archäologische Schriften 24, Habelt, Bonn.

Krausse, D., Fernández-Götz, M., Steffen, C., Wahl, J., and Otte-Scheschkewitz, P. (2013). Vom Burgberg zur Donau: Neue Untersuchungen zur Heuneburg (2008-2012). Archäologisches Korrespondenzblatt 43: 195-213.

Kurz, S. (2000). Die Heuneburg-Aussensiedlung-Befunde und Funde, Forschungen und Berichte zur Vor- und Frühgeschichte in Baden-Württemberg 72, Stuttgart.

Lambot, B., and Méniel, P. (1992). Le site protohistorique d'Acy-Romance (Ardennes), I: L'habitat gauloise, 1988-1990, Mémoire de la Société Archéologique Champenoise 7, Reims.

Mölders, D. (2010). Die eisernen Werkzeuge aus Bibracte: Ein Beitrag zur Erforschung des keltischen Handwerks nach den Arbeiten von Jacques-Gabriel Bulliot und Joseph Déchelette, Collection Bibracte 18, Centre Archéologique Européen, Glux-en-Glenne.

Mötsch, A. (2011). Der späthallstattzeitliche "Fürstensitz" auf dem Mont Lassois: Ausgrabungen des Kieler Instituts für Ur- und Frühgeschichte 2002-2006, Habelt, Bonn.

Nakoinz, O. (2013). Archäologische Kulturgeographie der ältereisenzeitlichen Zentralorte Südwestdeutschlands, Habelt, Bonn.

Nickel, C., Thoma, M., and Wigg-Wolf, D. (2008). Martberg: Heiligtum und Oppidum der Treverer I: Der Kultbezirk, Berichte zur Archäologie an Mittelrhein und Mosel 14, Koblenz.

Nicolai, C. von (2014). Sichtbare und unsichtbare Grenzen. Deponierungen an eisenzeitlichen Befestigungen in Mittel- und Westeuropa, Habelt, Bonn.

Peyre, C., and Buschsenschutz, O. (2008). Tite-Live, Bourges, et les premiers processus d'urbanisation à l'âge de Fer en France septentrional. Germania 86: 29-46.

Prammer, J., Sandner, R., and Tappert, C. (eds.) (2007). Siedlungsdynamik und Gesellschaft: Beiträge des internationalen Kolloquiums zur keltischen Besiedlungsgeschichte im bayerischen Donauraum, Österreich und der Tschechischen Republik, Sonderband der Jahresberichte des Historischen Vereins für Straubing und Umgebung, Straubing.

Ralston, I. (2007). Bourges and the earlier Iron Age: An interim view. In Gosden, C., Hamerow, H., de Jersey, P., and Lock, G. (eds.), Communities and Connections: Essays in Honour of Barry Cunliffe, Oxford University Press, Oxford, pp. 217-239.

Rieckhoff, S. (2002). Der Untergang der Städte: Der Zusammenbruch des keltischen Wirtschafts- und Gesellschaftssystems. In Dobiat, C., Sievers, S., and Stöllner, T. (eds.), Dürrnberg und Manching: Wirtschaftsarchäologie im ostkeltischen Raum, Habelt, Bonn, pp. 359-379.

Rolley, C. (ed.) (2003). La tombe princière de Vix, Picard, Paris.

Salač, V. (1993). Production and exchange during the La Tène period in Bohemia. Journal of European Archaeology 1: 73-99.

Salač, V. (2005). Vom Oppidum zum Einzelgehöft und zurück: zur Geschichte und dem heutigen Stand der Latèneforschung in Böhmen und Mitteleuropa. Alt Thüringen 38: 279-300.

Salač, V. (2013). Zwei Beispiele des Beharrungsvermögens in den Eisenzeitinterpretationen: Die Oppida und die Markomannen. In Karl, R., and Leskovar, J. (eds.), Interpretierte Eisenzeiten: Fallstudien, Methoden, Theorie, Studien zur Kulturgeschichte von Oberösterreich 37, Linz, pp. 233-246.

Sievers, S. (2010). Die Waffen aus dem Oppidum von Manching, Die Ausgrabungen in Manching 17, Wiesbaden.

Sievers, S., Leicht, M., and Ziegaus, B. (2013). Ergebnisse der Ausgrabungen in Manching-Altenfeld 1996 bis 1999, Die Ausgrabungen in Manching 18, Wiesbaden. 
Tappert, C. (2016). Les alentours des sites centraux: le développement et la structuration du territoire dans la vallée du Danube en Basse-Bavière à l'époque de La Tène. In Blanquaert, G., and Malrain, F. (eds.), Évolution des sociétés gauloises du second âge du Fer, entre mutations internes et influences externes, Revue Archéologique de Picardie № Spécial 30, pp. 147-166.

Thurston, T. (2009). Unity and diversity in the European Iron Age: Out of the mists, some clarity? Journal of Archaeological Research 17: 347-423.

Wells, P. S. (ed.) (1993). Settlement, Economy, and Cultural Change at the End of the European Iron Age: Excavations at Kelheim in Bavaria, 1987-1991, International Monographs in Prehistory, Ann Arbor, MI.

Wells, P. S. (2011). The Iron Age. In Milisauskas, S. (ed.), European Prehistory: A Survey, Springer, New York, pp. 405-460.

Wieland, G. (ed.) (1999). Keltische Viereckschanzen: Einem Rätsel auf der Spur, Konrad Theiss Verlag, Stuttgart.

Winger, K. (2015). Baubefunde und Siedlungsentwicklung der Südumgehung im Oppidum von Manching, Die Ausgrabungen in Manching 20, Wiesbaden.

Zeeb-Lanz, A. (2008). Der Donnersberg: Eine bedeutende spätkeltische Stadtanlage, Archäologische Denkmäler in der Pfalz 2, Speyer. 